\title{
La sigilosa sonoridad de un texto plástico: Frida Kahlo en el cine y en su pintura*
}

\begin{abstract}
*Este trabajo es parte de una investigación que, con beca del CNPq, realizo sobre Poética de la Imagen. Me incliné por escoger el tema de Frida Kahlo teniendo en cuenta dos razones: (1) después de una larga investigación sobre la obra de la pintora, me ha sido posible constatar que, a pesar de los numerosos libros dedicados a esta artista, la idea que aquí desenvuelvo no ha sido abordada en ninguno de ellos y (2), siendo así, considero que el asunto puede merecer un interés mayor por parte del público latinoamericano. Debo decir que, además de esas razones, mi estudio, acorde con algunas características de la pintura de la compañera de Diego Rivera, puede dar margen, en una etapa posterior, a una discusión de la hipertextualidad de sus autorretratos, tal como ese termino es entendido por Lew Manovich (2001:XV-XXXVI) y, por otro lado, caso el contenido de la conferencia cause mayores intereses, podré, también, ampliar mis observaciones destacando el papel que representa la obra de Frida en la dicotomía que, inspirándose en Foucault, Pere Salabert (2003: 210-230) señala como modelo posible para estudiar la evolución en la pintura occidental.
\end{abstract}

Eduardo Peñuela Cañizal Escola de Comunicações e Artes/USP 


\section{Resumo}

O artigo, considerando que Frida, filme de Julie Taymor, não explora a dimensão mítica da pintura, aborda aspectos da escrita ameríndia de um auto-retrato de Frida Kahlo, dando destaque ao papel que desempenha o rébus usado pela pintora mexicana para expressar sua relação com o universo mítico da deusa Xochiquétzal.

Palavras-chave

poética, imagem, expressão plástica, cinema, cultura e semiótica

\section{Abstract}

Considering that Frida, film directed by Julie Taymor, does not investigate the mythical dimension of painting, this paper explores some aspects of Amerindian writing in a self-portrait of Frida Kahlo, specifically the role of a rebus used by the Mexican painter to express her relationship to the mythical goddess Xochiquetzal, patroness of weavers and the art practiced by women.

Key words

poetics, image, plastic expression, cinema, culture and semiotics 


\section{Sobre la película}

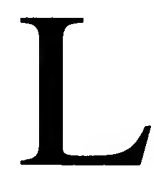

a película Frida (2002), dirigida por Julie Taymor, puede, sin que eso signifique menospreciar el texto fílmico, servirme, en esta ocasión, para plantearme algunas cuestiones

relativas a los problemas referenciales que presenta la adaptación de una obra biográfica sobre la celebrada pintora mexicana y, sobre

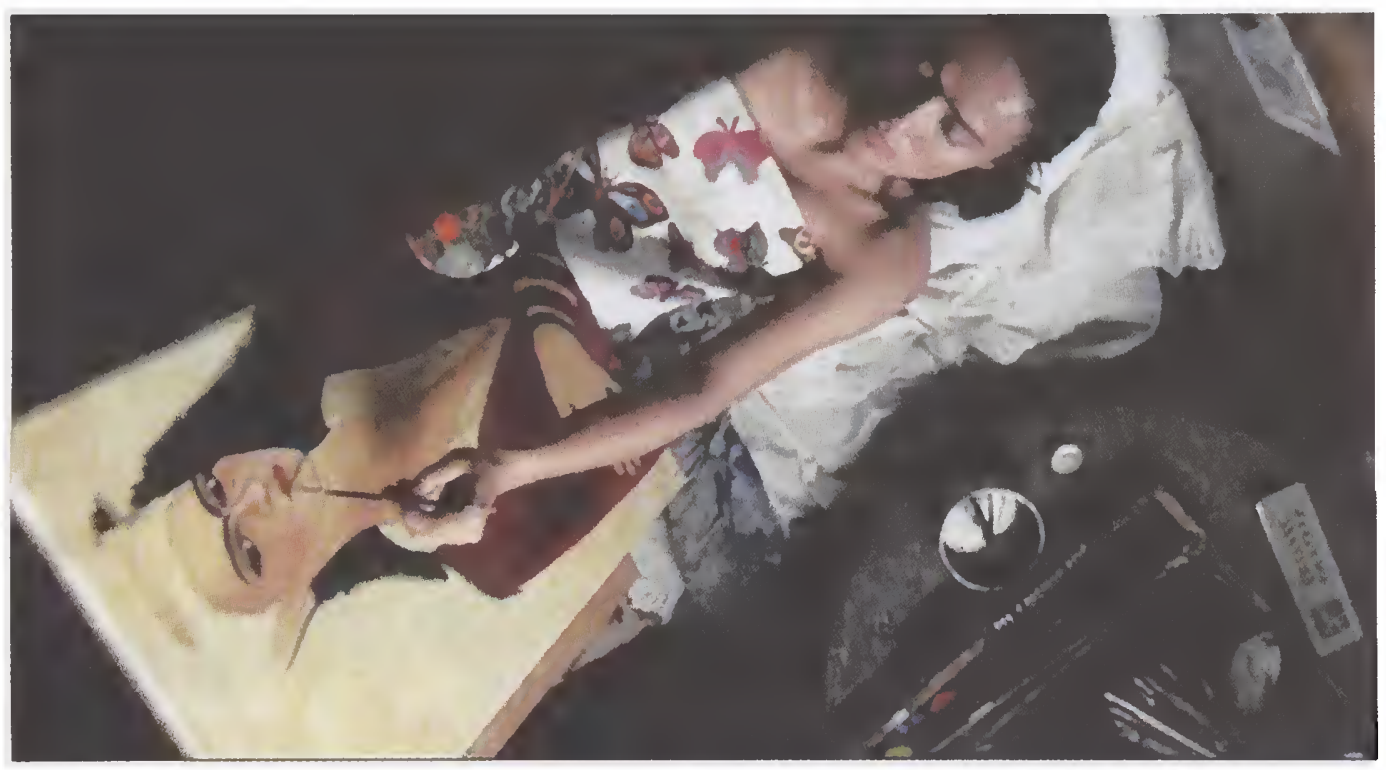

todo, para abordar algunos aspectos concernientes a la sigilosa sonoridad de uno de los autorretratos más conocidos de esta artista, particularidad que en ningún momento es explorada en la adaptación fílmica, mucho más comprometida en abordar los simbolismos de superficie que en adentrarse en las significaciones culturalmente más recónditas de las iconografías amerindias que se infiltran, a menudo, en muchos de los textos pictóricos de Frida Kahlo. No pretendo, sin embargo, profundizar en el análisis de la cinta, ni tampoco acercarme, 
con intenciones interpretativas, al conjunto de la producción pictórica de la compañera de Diego Rivera. Mi intención, en el fondo, no deja de ser modesta, aunque pueda parecer pretenciosa. Parto del principio de que la adaptación fílmica del libro de Hayden Herrera(1983) ${ }^{1}$, fiel en muchos sentidos, mantiene también la fidelidad en lo que concierne al descaso por el que pasan muchos de los aspectos míticos que envuelven la figura y la obra de Frida Kahlo, lo que, a mi entender, pone en evidencia un rasgo que me instiga y, de cierto modo, me molesta. O sea, al dejar de lado trazos significativos de la cultura amerindia, los realizadores asumen abiertamente una actitud colonizadora que se proyecta avasalladoramente en el texto de la película $\mathrm{y}$, en consecuencia, aguijonean las pupilas del espectador con ideologemas que reprimen todo lo que no pertenezca al imperio de la cultura dominante y, así, reducen, con frecuencia, las posibilidades de lectura no sólo del texto fílmico, sino también de los textos plásticos que en él se representan.

Es obvio que el espectador de un film no tiene el derecho de exigir que la película tenga lo que él desea, pero como, en el caso, Julie Taymor utiliza, casi siempre, los cuadros de la pintora como una especie de escenario cuya iconografía serviría para explicar la personalidad de su personaje, me siento atraído por la idea de que, al no haber sido abordados por la cineasta los sentidos míticos de esos cuadros, el espectador que consiga convivir con alguno de ellos podrá constatar la existencia de un vacío en el texto fílmico propiamente dicho o, entonces, teniendo en cuenta que el espectador tiene también un papel en la enunciación de la cinta, realizar una lectura en que la falta se recompensa a través de las añadiduras que ese mismo espectador puede inserir en las imágenes valiéndose de elementos provenientes de los llamados códigos de recepción. En buena parte, la película invita a esa tarea y, en el fondo, la facilita, pues está construida a partir de un punto de vista centralizador, medio encontrado por los realizadores del film para traducir la visión que nos da el

1. Cito la edición en inglés - Frida, a Biography of Frida Kahlo. Harper and Row, New York, 1983 -, pero utilizo en esta ocasión la edición francesa de esa obra aparecida en 1996. 
libro de Hayden Herrera y, claro, la visión que podría garantizar un portentoso éxito de público.

Unos ejemplos me permitirán plantear tales cuestiones de manera más clara. Así, en el juego de usar como trasfondo de las escenas más tensas pinturas de Frida Kahlo, se presiente la presencia de otro libro de Hayden Herrera. Me refiero a Frida Kahlo. Las pinturas (1994), obra en que la autora va exponiendo los datos más relevantes de la vida de la artista utilizando la técnica de poner en contrapunto las informaciones escritas e iconográficas, cuadros, dibujos y fotografías. Cuando relata el episodio del aborto, pongo por caso, ilustra sus informaciones con un dibujo sobre la operación cesárea y la pintura titulada Hospital Henry Ford, de 1932, para decirnos que

Frida yace desnuda, llorando y con hemorragia sobre una única sábana. Al igual que Cuatro habitantes de México, el espacio es un abismo de pesadilla en el que Frida parece flotar. Dijo que había pintado el suelo color tierra para expresar su soledad. En el horizonte, distante e inalcanzable, está la Ford Motor Company, donde Rivera, lleno de entusiasmo ante la moderna industria, trabajaba activamente preparando los bocetos para sus murales. Frida se mira diminuta en comparación con su cama y dentro del plano en el que flota. (1994, p. 70)

Emana de esas observaciones un ton melodramático, característica que impregna casi todos los comentarios de Herrera y que, a lo que me parece, persiste también en la película, si bien los críticos insisten en clasificarla como drama y en ver su realismo por el prisma de escenas como la que nos presenta a Frida en la cama del hospital mediante una composición en que aparece, en primer plano, el frasco que contiene un feto.

El matiz de melodrama se nota en muchas otras secuencias y aun en las que tienen un explícito carácter político, como ocurre con la que antecede a la destrucción del mural que Rivera estaba concluyendo en el Rockefeller Center. Ahí la expresividad de los 


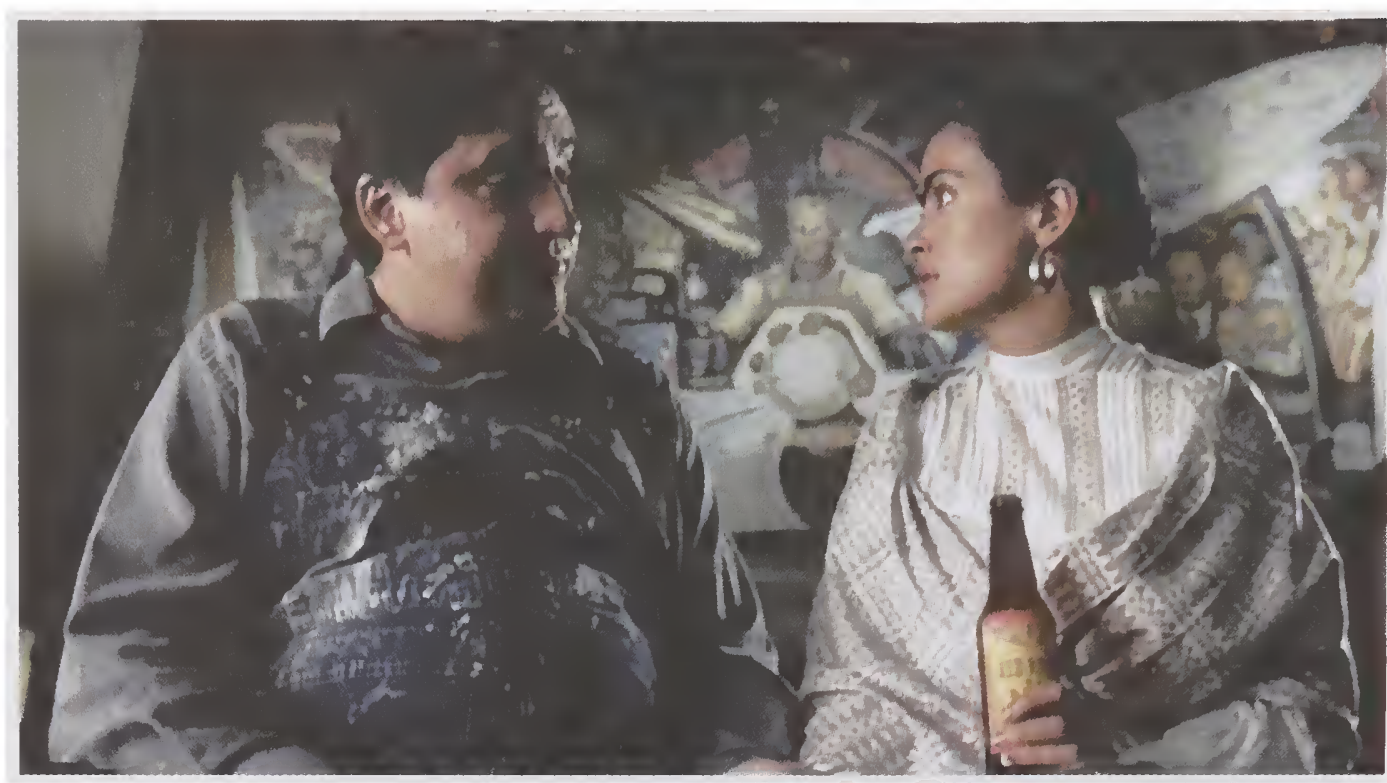

actores, con el mural al fondo, se hace, en su aparente sencillez, calculadamente exagerada ${ }^{2}$.

Por otro lado, sería injusto afirmar que la película no intenta utilizar otros recursos, otras maneras de leer la relación entre la pintura y la vida de Frida Kahlo. Existen pasajes en que los realizadores se lanzan a la tarea de reproducir las iconografías por medio de escenas vivas que las imitan. Tal sucede, pongamos, en los episodios posteriores a la traición cometida por Rivera con la hermana de Frida Kahlo. En esta ocasión, la película aborda el tema basándose, sin descartar otras fuentes, en el Autorretrato de pelona ${ }^{3}$ y, a través de un juego de espejos, multiplica las imágenes no sólo para articular el laberíntico del estado de alma del personaje, sino también para ampliar las dimensiones del conflicto. Pero, aun así, los realizadores, a pesar de la belleza del fragmento, intensifican el ton melodramático $y$, de cierta manera, traducen con los lenguajes del cine la interpretación que de esa pintura nos dejó Hayden Herrera cuando afirma que en ella

2. La composición de este plano recuerda, en parte, la que utiliza Lucienne Bloch en la foto que Isabel Alcántara y Sandra Egnolff reproducen en Frida Kahlo and Diego Rivera (1999:42).

3. Cabe observar que es uno de los pocos momentos del film en que se aprovecha el género autorretratístico, lo que es curioso en una película que se vale constantemente de otros géneros pictóricos practicados por Frida en cuanto componentes del escenario y más curioso aún cuando se piensa que la película entera es una especie de autorretrato. 
Frida se ve como uno de esos santos mutilados que tanto fascinan al catolicismo mexicano. En la mano izquierda sostiene un mechón de su cortado cabello como un emblema de su sacrificio. En su mano derecha sostiene unas tijeras con las que martirizó su feminidad. Un estado de ánimo de furia reprimida se evidencia mediante los colores tan ácidos que nos hacen rechinar los dientes. La misma furia se expresa por medio de la ropa agresivamente fea de Frida. Se ha quitado su traje de tehuana que proporcionaba tanto placer a Rivera y se ha puesto un traje oscuro demasiado grande para ella y que debe ser de él. Debido a la importancia que Frida daba a la ropa, el portar un holgado traje de hombre era como llevar un cilicio o el hábito de una monja. El único vestigio de su feminidad son sus aretes. (1994, pp.151-152) .

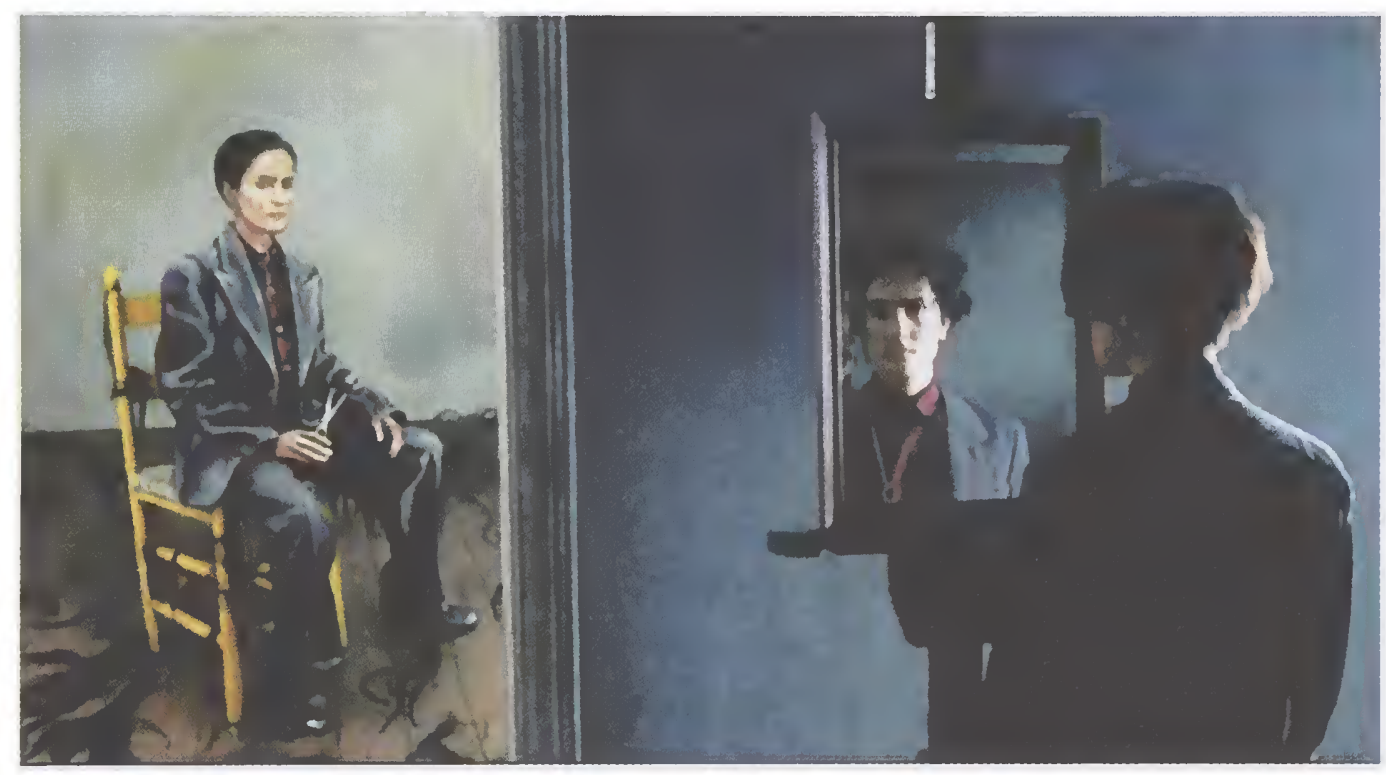

En otras secuencias, la película se aproxima a ciertos valores simbólicos de la cultura mesoamericana y se vale de ellos - por lo menos

4. Queda la impresión de que, en ese comentario, Hayden Herrera se olvida de las tendencias sexuales de la pintora y, sobre todo, pasa por alto el hecho de que, aún muy joven, Frida fue retratada - precisamente un retrato de familia - por su padre vestida de hombre y con el pelo recogido, hecho que el film registra en una escena que tiene por fondo musical un tango. Con respecto a esa ambigüedad del personaje, se puede decir que la actitud de Julie Taymor es más clara y contundente, pues, de cierta manera, Hayden Herrera siempre se las arregla para atenuar, de algún modo, la bisexualidad de Frida. 
de sus capas más evidentes - para sublimar de algún modo las relaciones entre los personajes principales. Eso se constata, pongo por caso, cuando, ya conscientes de su mutua atracción, Frida y Trotsky ${ }^{5}$ suben las escaleras de la Pirámide del Sol y, una vez en su cumbre, la cámara nos ofrece una visión panorámica en que la gran pirámide se ha transformado en la escalinata de una pareja puesta allí por los dioses para reinar sobre un mundo que se hace pequeño a sus pies.

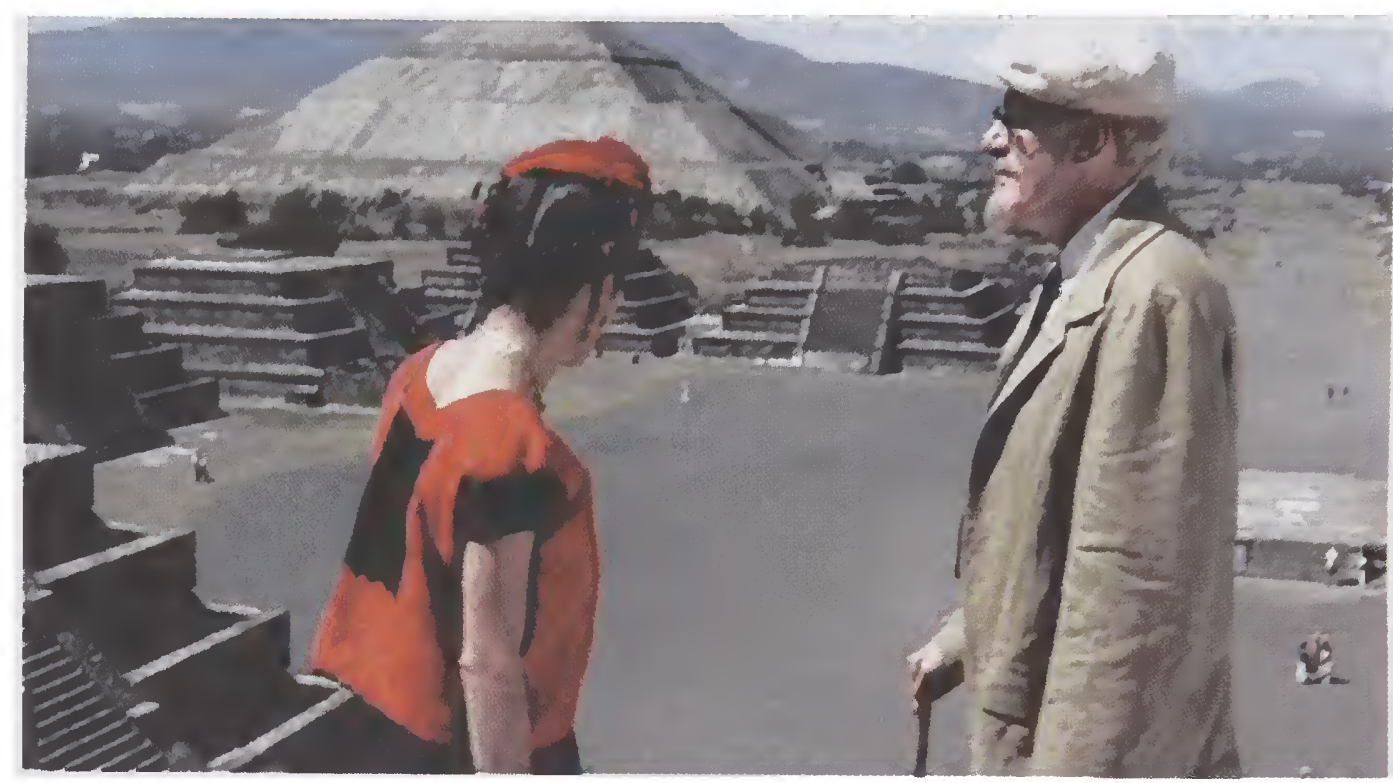

Vista con atención, la construcción de esa secuencia se aleja mucho de los contrapicados que Eisenstein nos dejó, en Que Viva México, de mismos lugares míticos. En la obra del cineasta ruso, la extraordinaria geometría de los monumentos indígenas empequeñece a los seres humanos, mientras que en el film de Julie Taymor lo que mengua son los signos de una cultura subyugada, aunque la panorámica preserve la grandiosidad de las edificaciones y los personajes hayan sentido, en el esfuerzo de subir los tramos de la gran pirámide, la fatiga de una metáfora primordial: la que se engendra en el viaje de subida hacia los señoríos del sol.

5. Creo que la relación entre Frida y Trotsky fue tratada de manera unilateral por los realizadores del film. Quien haya leído La casa azul de Coyoacán. El triángulo amoroso de Trotski, Frida y Diego Rivera, de Meaghan Delahunt (2002) podrá comprobar eso, pues la autora de esta novela-ensayo, publicada en inglés en 2001, se utiliza de varias fuentes, inclusive del Diario escrito en Coyoacán por el pensador ruso, lo que confiere al episodio matices en los que Hayden Herrera no entra. 
Hay que reconocer, sin embargo, que, en determinados pasajes, las imágenes se sublevan contra les efectos de la opresión, principalmente en los momentos del film que se refieren a los hechos vividos por Frida y Diego Rivera en los Estados Unidos. Para acentuar el acto de salvajismo prepotente cometido contra el célebre mural del Rockefeller Center, destruido en mayo de 1933, los realizadores metaforizan el salvajismo del acto colocando una cortina enorme que cubre el cuerpo del texto pictórico, como las sábanas del hospital Henry Ford cubren el cuerpo mutilado de Frida Kahlo. Además, ese lienzo encubridor expresa, a través de su densa opacidad, el efecto de los ideologemas imperialistas y, en las ondulaciones de su tejido burdo, lo reprimido, a pesar de sofocado, deja las marcas de un inconsciente político que se conduele del ennegrecido destino a que son sometidos los signos marginados por la prepotencia. Pero como protesta a la brutalidad de ese tipo de acciones, descuellan dos imágenes-clave: la que evoca la primitiva sencillez de unas ropas tendidas en una terraza casi aldeana y la que muestra la invasión de la intimidad de Frida en su bañera, tal cual plasmada por la pintora en una de sus obras más enigmáticas: Lo que me dio el agua (1938).

En la primera, una perspectiva en abismo nos coloca ante la presencia de una visión nostálgica consagrada por ese instante de plenitud que Frida, en Recuerdo (1937), representa a través de unos vestidos que parecen estar colgados de los nubarrones de un cielo tormentoso. Poco importa, considerando los propósitos, si los realizadores del film respetan o no la cronología de los hechos. El caso es que, de repente, parte de ese cuadro surge ante las pupilas del personaje enmarcado por una ventana a través de la cual se ve ese mismo vestido flotando sobre un paisaje urbano en que los fríos del alma se coagulan en copos de nieve.

Menos nostálgica, pero delatora de los muchos modos que asume la violencia, es la segunda imagen. Según los comentarios ${ }^{6}$

6. El lector debe haberse percatado que insisto en citar las obras de Hayden Herrera. Podría citar comentarios de otros autores, mas, en razón de los propósitos de este trabajo y también teniendo en cuenta que el film se inspira en la visión que esa estudiosa nos dejó de la vida y la obra de Frida Kahlo, creo que mi insistencia se justifica. 


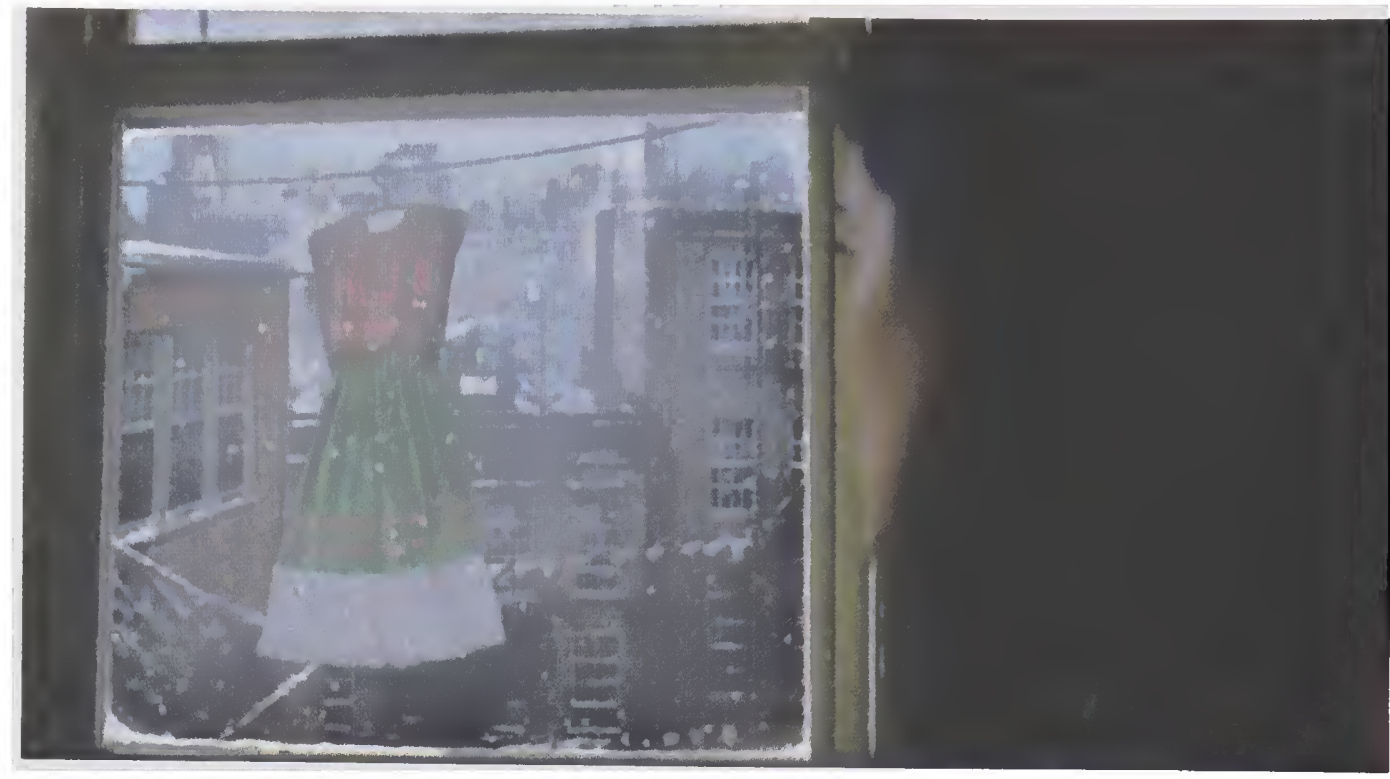

de Hayden Herrera (1994, p. 127), Lo que me dio el agua se referiría a la imposibilidad de Frida para concebir un hijo y, también, a la posible muerte del capitalismo simbolizada por la imagen del Empire State Building "atrapado en el humeante cráter de un volcán en erupción". De cualquier modo, en la secuencia de la película, lo que tenemos es una inversión, en parte, de esos significados,

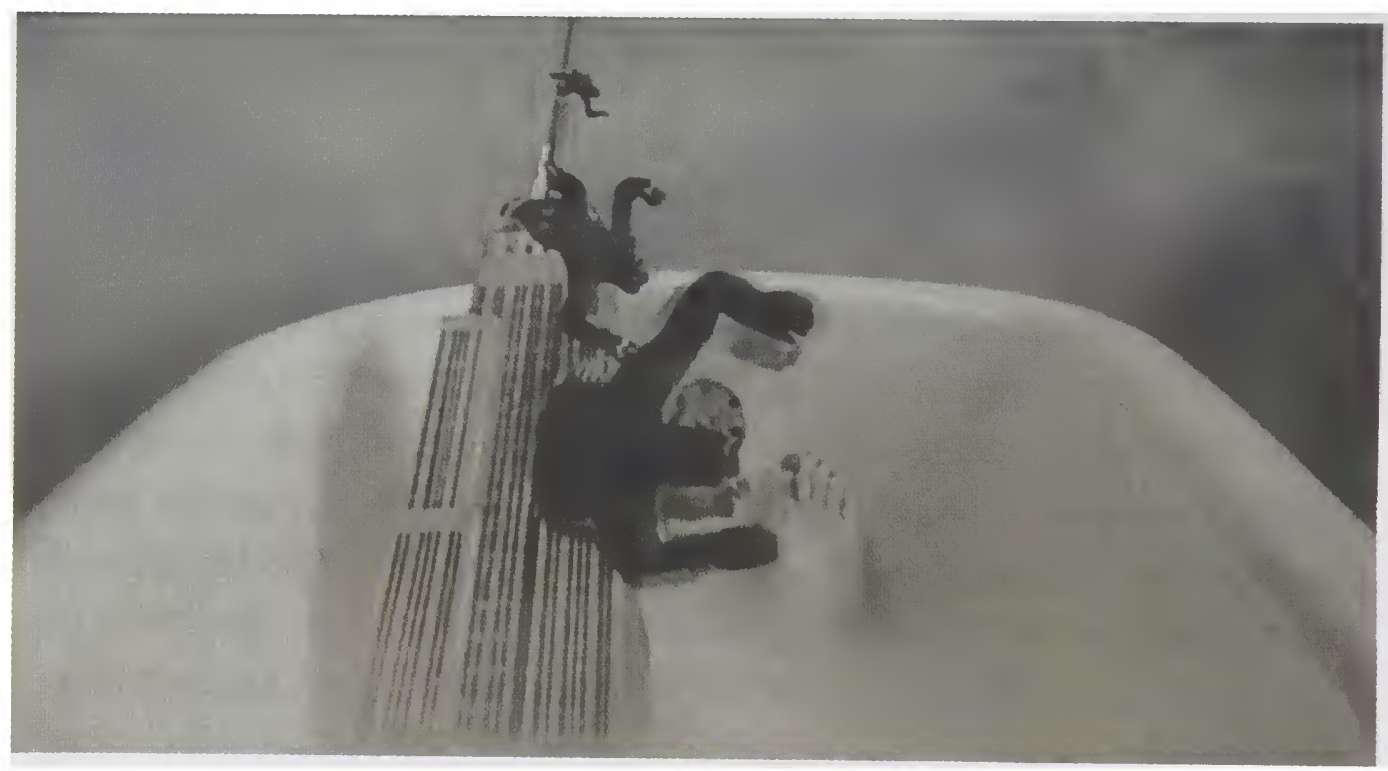

pues, aquí, el bueno de King Kong se desploma y el famoso edificio, aunque manteniendo su integridad, se derriba e invade el espacio de la privacidad plasmado en por la pintora ${ }^{7}$.

7. Claro que el cuadro original de Frida Kahlo posee sentidos enigmáticos en los

$\overline{\text { Significação } 20 \bullet 36}$ 
Algunos le niegan al cine la capacidad de funcionar como metalenguaje por medio del cual se puede realizar la lectura de un texto pictórico o la representación del universo de lo onírico ${ }^{8}$. Estoy convencido de que todo es representable y de que el cine, en cuento código en que se imbrican varios lenguajes o en cuanto lenguaje en que varios códigos se integran ${ }^{9}$, reúne recursos para montar la interpretación de un cuadro. La película de Julie Taymor nos deja prueba de ello, teniendo sus momentos más significativos en los pasajes de animación. La utilización de tal artificio no le quita méritos, al contrario, son precisamente esos trozos de la narración fílmica los que, en términos expresivos y poéticos, se destacan. Ya me he referido a algunos de ellos, pero me gustaría finalizar esta parte mencionando el que aparece al comienzo, después del relato del accidente

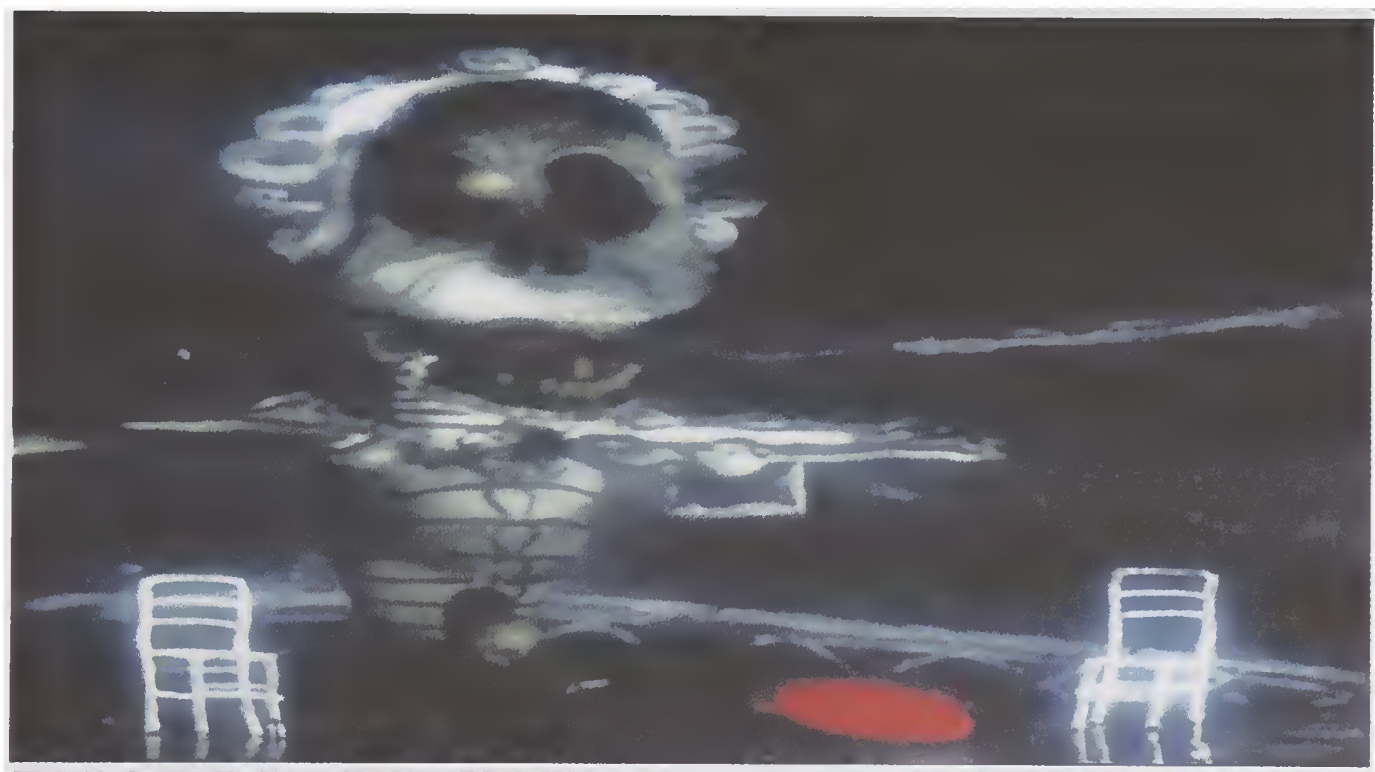

que no se detiene Hayden Herrera, basta fijarse en lo insólito de algunas de sus imágenes y recordar la atracción que los surrealistas sentían ante ellas para intuir el poder de su ambigüedad.

8. Creo que la cuestión se vincula al problema relacionado con la representación de las imágenes mentales y tiene sus raíces, como observa Costa (1995, p. 194), en el presupuesto, defendido por Jean Mitry, de que la representación de una imagen mental no sería esa imagen. Tal premisa es errónea por la simple razón de que cualquier imagen representada no es la imagen, sino la representación de la imagen. Desde este punto de vista, el cine puede muy bien representar lo que sea, una imagen mental, un sueño o un paisaje.

9. Ideas defendidas por Christian Metz en su ya clásico libro Langage et Cinéma (1977, pp.17-27). 
de Frida, y el que encierra la película. Por lo que toca al primero, entendido como tentativa de plasmar el mundo interior del personaje y las alucinaciones que en él se debaten, creo que la cinta supo captar particularidades muy significativas de la pintura y del contexto cultural en el que se movía la compañera de Rivera. Sacando provecho de las iconografías de la muerte, el conflicto de sombras que habría sido vivido por Frida en el transcurso de la cirugía, se transforma en una sinfonía de fantasmas cadavéricos concentrados en el manejo de instrumentos de incisión.

Y, finalizando ese ritual en el que las fronteras entre la vida y la muerte parecen haber desaparecido, dos calaveras de esos muñecos de la imaginación depositan sus formas sobre los ojos de Frida Kahlo convirtiéndose, de pronto, en ominosas pupilas.

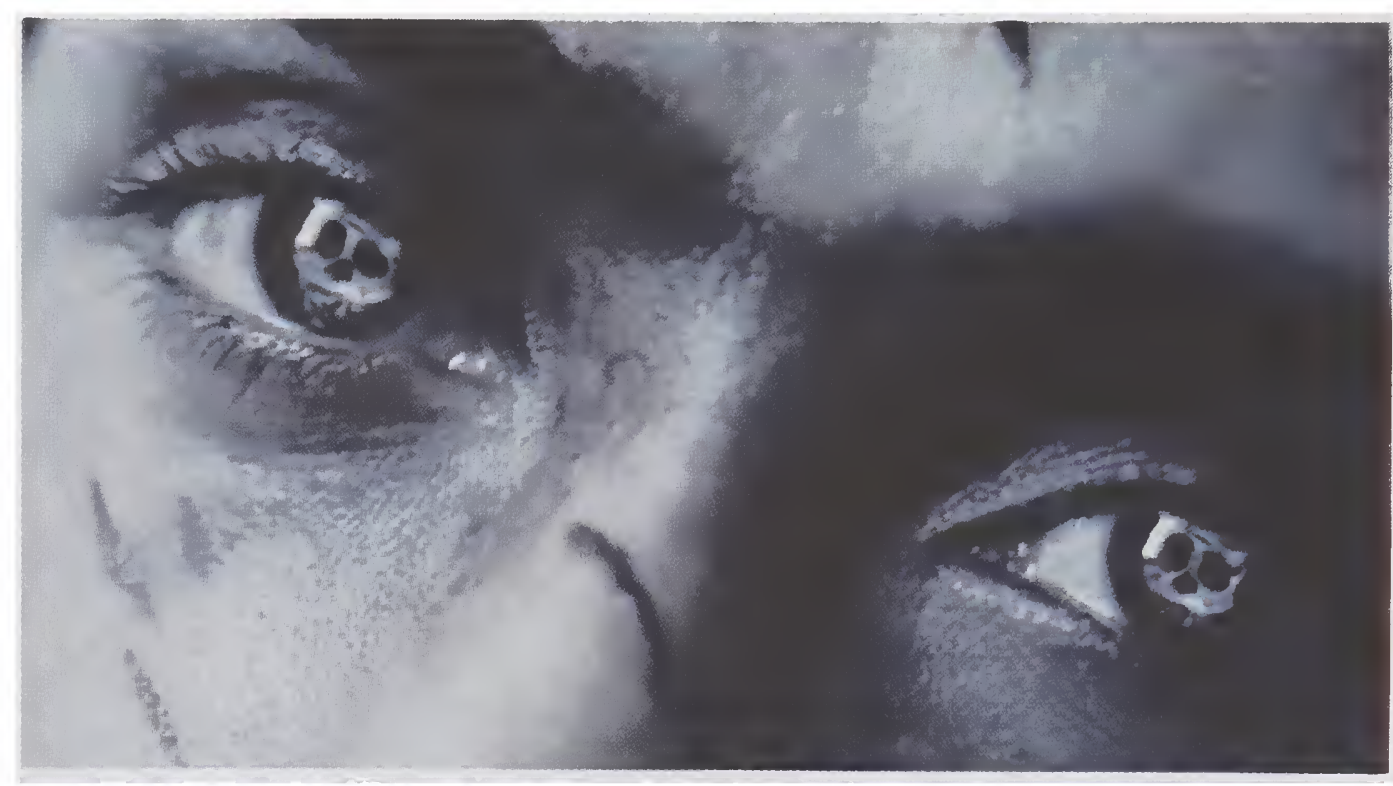

La metáfora se presenta sin ambages, aunque, como toda metáfora visual, tiene raíces en iconografías distantes, en iconografías que el tiempo se encarga de remodelar y fijar sus figuras en las más diversas combinaciones. Se puede alegar que, tal como articulada, la composición de esa imagen se vincula a la tradición iconográfica de que se vale Escher en algunas de las obras realizadas durante la segunda década del siglo pasado o, entonces, teniendo en cuenta analogías más precisas aún, al famoso Ojo (1946) representado por este artista mediante el proceso poético de sustituir la pupila por una calavera. Aunque esa intertextualidad me resulte evidente, el 
compromiso de la imagen fílmica en pauta con la tradición iconográfica es, sin duda, más directo. Por eso, no menospreciando la carga de lejanías que este tipo de metáfora lleva consigo, creo que, en este fragmento animado de la película, el espectador puede encontrar los trazos de una escritura iconográfica que Frida Kahlo capta en algunos de sus cuadros: Cuatro habitantes de México y Niña con máscara de muerte, ambos de 1938. El motivo de la calavera surge también en algunas de sus pinturas, siendo la más representativa a ese respecto la obra titulada Pensando en la muerte (1943), un autorretrato en el que ese símbolo ancestral, al igual que una mariposa fúnebre, no se posa en los ojos de la mujer, sino en su frente, formando con las alas de pájaro herido de sus cejas una singular configuración. Creo, sin embargo, que el ritual de la película tiene sus antecedentes iconográficos más cercanos en la composición La mesa herida, de 1940. Con sus piernas despellejadas, la mesa es una suerte de tablado sobre el cual los fantoches de la muerte colocan en escena saltimbancos que se entregan a una enigmática carnavalización. Es como si Frida Kahlo hiciese poesía mediante el recurso de colocar las cosas fuera del lugar que la costumbre y la comodidad le destinan ${ }^{10}$

Por consiguiente, que una cama vuele ya es motivo suficiente para que la poesía tenga más espacio y que esa cama arda, como en la imagen final de la película, puede ser el signo más apropiado para expresar la pulsión de muerte que, como el sueño, no nos separa del mundo, sino que nos hace mundo. En fin, vale decir que el film, en ciertos momentos, nos envuelve y casi nos invita a que seamos cómplices de una ambigüedad contagiante o, en otras palabras, de una ambiguiedad en que, aunque ausente, la resonancia de una escritura indígena nos abre la posibilidad de que, en cuanto sujetos activos de la enunciacion, realicemos una tentativa de lectura fundamentada

10. No hay que olvidar la influencia que a respecto del tema de la muerte, presente también en varias pinturas de Rivera, ejerce la obra singular de José Guadalupe Posada. Pero aún podrian rastrearse, en el juego de intertextos puesto en marcha por las animaciones de la película, otras iconografías, principalmente obras de artistas plásticos chicanos como Bear, Nierman, Chagoya y Batuc, para citar tan sólo algunos. En lo tocante a las escenas de animación, me parece que puede ser importante estudiar las iconograflas de esas escenas con algunos pasajes de animación de películas de Robert Rodríguez. 
sobre lo que nos parece que a la película le falta o que el texto fílmico nos niega.

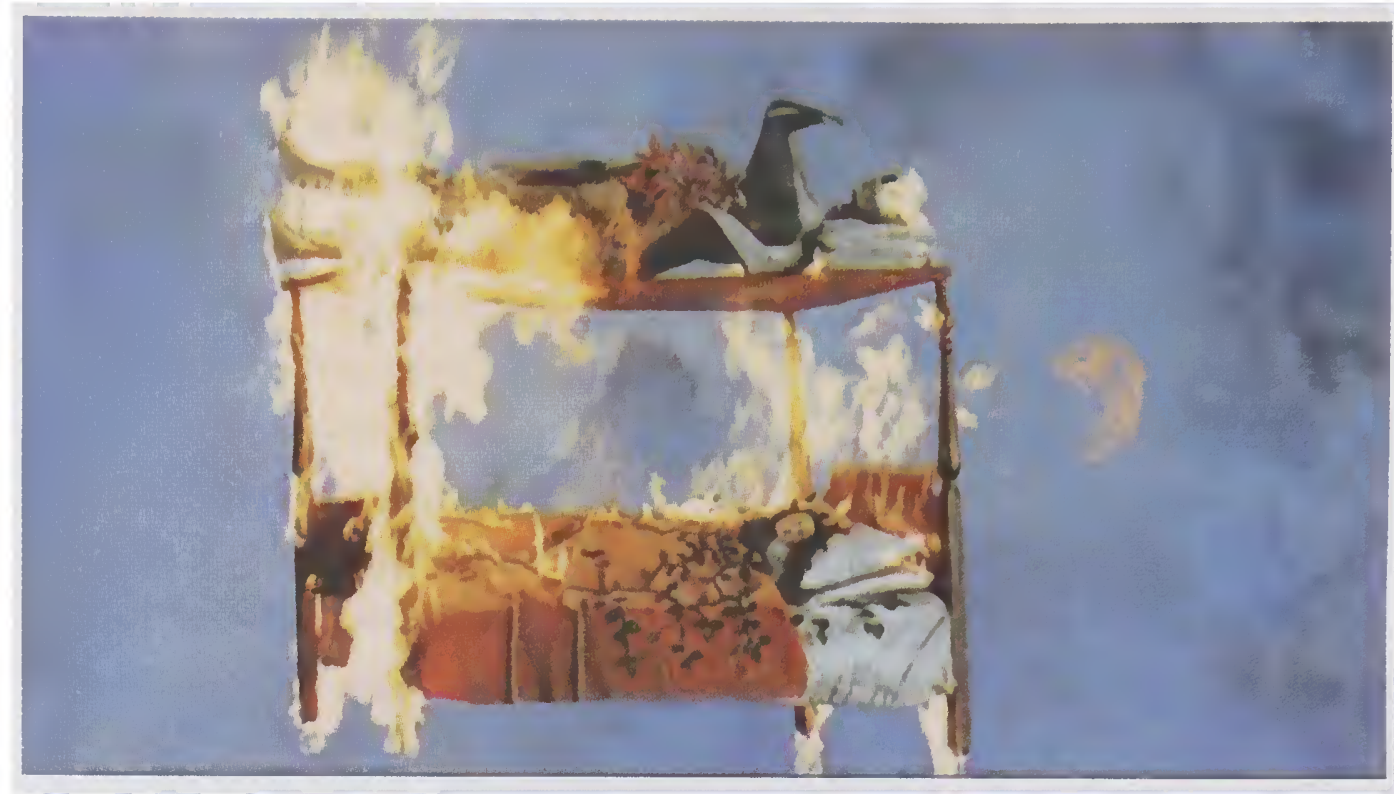

\section{Sobre el rebus}

Raúl Dorra, en el ensayo titulado Artes de la mirada (1999, p. 188), parte del principio de que la lectura no consiste en el elemental ejercicio de pasar los ojos sobre los signos impresos, ya que éstos están en el texto escrito para evocar el sonido de las palabras o sea, el sonido sostiene su presencia bajo la letra impresa pues ésta, en verdad, no anula la composición del signo lingüístico en la que el significante es siempre una imagen acústica y no una imagen visual. En el caso específico de un texto pictórico, tal premisa me parece igualmente válida. Convivo con la convicción de que el sonido mantiene su presencia bajo la configuración plástica propiamente dicha, sin negar con eso que una parte esencial de esa especie de latencia ${ }^{11}$ sonora provenga de la traducción verbal: vemos la imagen, le damos el nombre correspondiente y por medio de esa operación avivamos la articulación de fonemas del signo linguístico utilizado para identificar la imagen. Tal operación es, sin duda, fundamental, pero no es la

11. Para que se tenga una idea más abarcadora de lo que aquí significa este término, recomiendo la lectura del Capítulo IV del libro de Kaja Silverman titulado The Acoustic Mirror (1988, pp. 101-140). 
lectura cabal de un cuadro, pues así como determinados femas pueden intervenir en la construcción del plano de la expresión de la imagen acústica evocada, del mismo modo determinados rasgos de los signos plásticos pueden interferir y transformar las relaciones de semiosis instituidas por la mediación de las unidades lingüísticas en el momento que, pongamos, se designan con nombres componentes icónicos del complejo espacio semiótico de un texto pictórico. Ese juego de transmutaciones expone su evidencia cuando, por ejemplo, el título integra el campo visible de una obra de pintura o cuando letras o frases son inseridas en ese campo, como ocurre en Ceci n'est pas une pipe o en Une étoile caresse le sein d'une negréese. En esos cuadros, la imagen acústica de los vocablos y las imágenes acústicas de los signos plásticos se mezclan $\mathrm{y}$, si se nos ocurre anclar la interpretación en los indicios designativos que las lenguas naturales nos propician, caeremos, irremediablemente, en la trampa de lo reductor y ahuyentaremos muchas de las resonancias figurales que se acurrucan en la urdimbre de las representaciones plásticas.

No resulta sorprendente, por tanto, que, con frecuencia, los títulos de un cuadro afecten su lectura y condicionen su interpretación a la semiosis de los signos verbales. Sin embargo, hay que admitir que, a menudo, la previa sonoridad de las palabras escritas obstruye, con más o menos fuerza, el proceso de escucha, pues ellas obstaculizan $^{12}$, con cierta eficacia, el sonido de la imagen cuando ésta se presenta no sólo como una combinación de signos impregnados de fuerte carga icónico-indicial, sino también como un modo posible de escritura $\mathrm{o}$, dicho con otras palabras, como una práctica significante en que sonidos e imágenes, creo, toleran una mutua convivencia. Por eso, aunque mucho se haya escrito acerca del carácter derivado o autónomo de la escritura en relación con lo oral y no exista, hasta hoy, una posición consensual sobre el asunto, desertaré de tal polémica y aquí trabajaré con la hipótesis de que la imagen pictórica, al comprometerse con una forma de escritura, implica, de manera más o menos evidente, la presencia de lo sonoro. No se debe olvidar que,

12. José María Nadal, en un ensayo dedicado al estudio de los vínculos entre palabras e imágenes en la pintura de Magritte, se refiere "a la guerra de lenguajes" que se manifiesta en ciertos cuadros del artista belga (1999, p. 124). 
a su vez, un fonema implica también la presencia de lo visual. Basta recordar, por ejemplo, que la realización del fonema $/ \mathrm{r} /$ requiere que la punta de la lengua haga un movimiento rápido hacia arriba y atrás, tocando los alvéolos para cerrar, aunque sea por un instante, el paso del aire. El gesto de la lengua dibuja, por consiguiente, una imagen que podrá ser "vista" en el momento que escuchamos el fonema o lo reproducimos mentalmente. Algo semejante sucede con las experiencias acusmáticas, esto es, con composiciones que utilizan sonidos y ruidos para evocar, entre otras cosas, particularidades visuales de un paisaje o de una ciudad, aunque aquí la indicialidad de los signos sea mucho más evidente.

Lidiar, pues, con esas ideas presupone admitir que las relaciones entre lo sonoro y lo visual presentan gamas muy distintas y que existen casos en que el vínculo entre tales elementos sensoriales, aun cuando aparezca de manera enigmático, pone de manifiesto, una vez descifrado el texto en que se realiza, singularidades propias de un sistema. En prácticas significantes en que la conciencia inmediata y la conciencia de presencia plena desempeñan conflictos que favorecen la significación poética, los procesos de escritura debilitan, con relativa frecuencia, la conexión entre los sonidos y las imágenes, como me parece haber dejado claro Per Aage Brandt (1999, pp. 7185) en su análisis de algunas obras de Magritte. Para este autor, lo que, al final de cuentas, caracteriza la expresión artística es, precisamente, la tendencia a suspender las rutinas mentales $\mathrm{y}$, con eso, posibilitar que la conciencia entre en contacto con mecanismos de descomposición y recomposición que pasarían desapercibidos en los llamados estados de normalidad. Desde esa perspectiva, la semiosis que se engendra en ese tipo de conexión enflaquecida propende a instaurar una pluralidad de significados cuyas consecuencias, en lo que se refiere al enlace de la sonoridad con las imágenes, aportan resultados ambiguos y polivalentes ${ }^{13}$.

Algunas de las cataduras connotativas que señala Michel Foucault (1973) en sus comentarios a Ceci n'est pas une pipe ilustran

13. El libro A History of Reading, de Alberto Manguel (1996), presenta un conjunto de perspectivas que pueden ser de gran utilidad para estudiar ciertos matices de la relación de lo visual con lo sonoro.

Significação $20 \bullet 42$ 


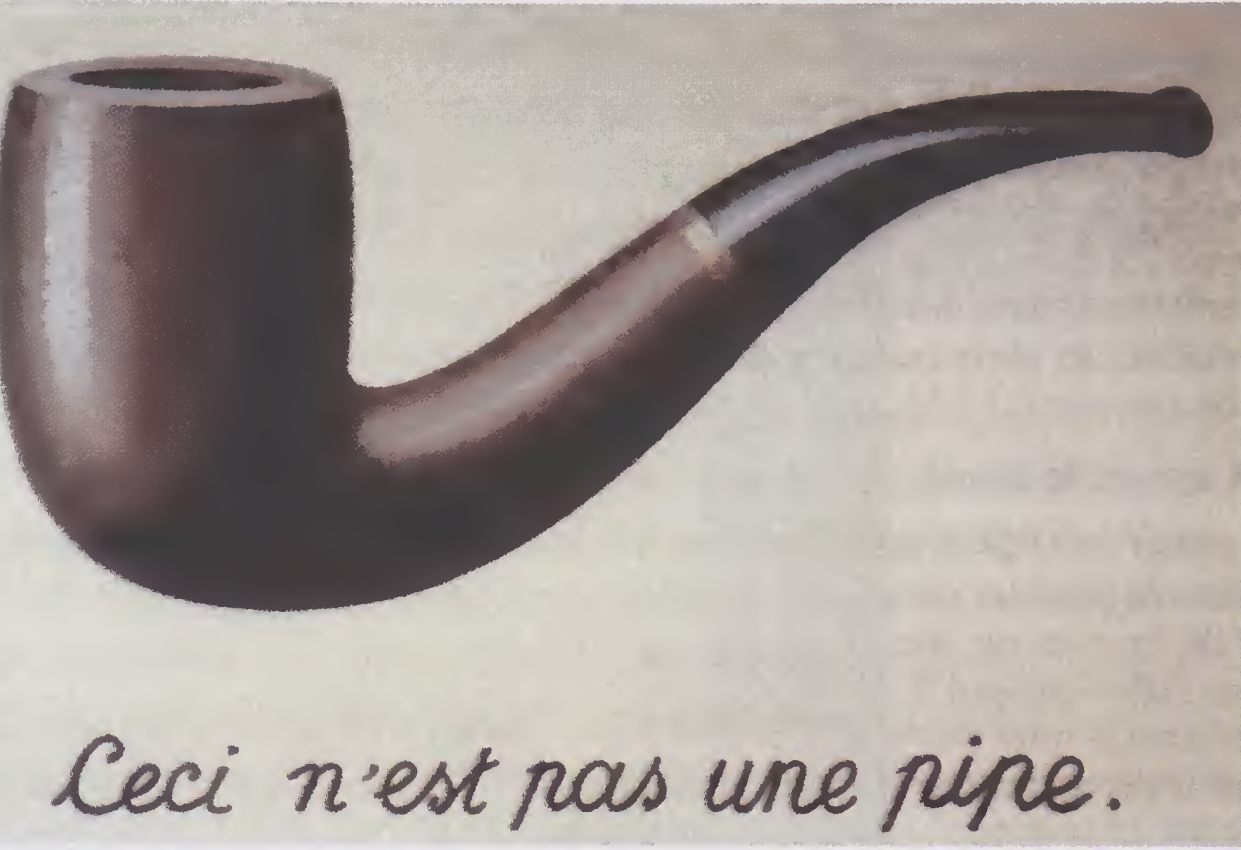

bien el tipo de escritura en que la relación entre la palabra, en cuanto elemento evocador de lo sonoro, y la imagen se relaja. El cuadro es un texto que simula un texto: el dibujo de una pipa que finge ser un dibujo o el simulacro de una pipa dibujada como una pipa que se niega a ser sencillamente la imagen de ese objeto. Pero es evidente que el espacio semiótico resultante de la combinación de diferentes tipos de signos crea una especie de intratextualidad sin que lo propiamente icónico de los significantes verbales y pictóricos sufra cualquier alteración expresiva relevante. Todo parece habitual en esta obra y, sin embargo, hay en ella una sutil capa de ominosidad, algo que evoca el eco tenue de ese instante único en que el referente recibe un nombre que lo legitima como signo $\mathrm{y}$, por consiguiente, preserva, de algún modo, reminiscencias de un acto sensible, aunque lejano en el tiempo y en el espacio.

Algo semejante sucede en el cuadro de Miró. Si bien la ambigüedad sonora también está presente, las letras de Une étoile caresse le sein d'une negréese desobedecen el principio de la linealidad de la escritura verbal y la rima que se observa, por ejemplo, en caresse y négresse, se reitera, a través de los juegos cromáticos, en el ámbito de lo plástico. Mediante tales recursos, el pintor catalán instituye una especie de combinación que añora no sólo resonancias 
intrauterinas - rumores de ese acontecimiento que se consuma entrañablemente en la interioridad del cuerpo maternal -, sino también el ruido de ondulaciones marítimas. En rápida acotación, PunyetMiró y Lolivier-Rahola se refieren a este cuadro-poema diciendo que en él se establece un posible juego entre las inscripciones sensuales y poéticas y las formas de colores lisos, produciendo un efecto de sorpresa y de placer. (1998, p. 62)

Todo parece indicar que los marcos sonoros y plásticos, cuando se aglutinan, producen una expresividad envolvente que se aproxima a lo que, según Kaja Silverman (1988, p. 102), Julia Kristeva define como "xora", esto es, como una insólita "semiotic disposition" bajo la cual se cobija un "geno-text" en el que se asocian ideas acerca de la madre y de la prehistoria del sujeto, un genotexto afectivo comprometido con el papel que desempeñan la voz materna, el rostro, el seno y las condiciones psicolibidinales de la temprana vida embrionaria.

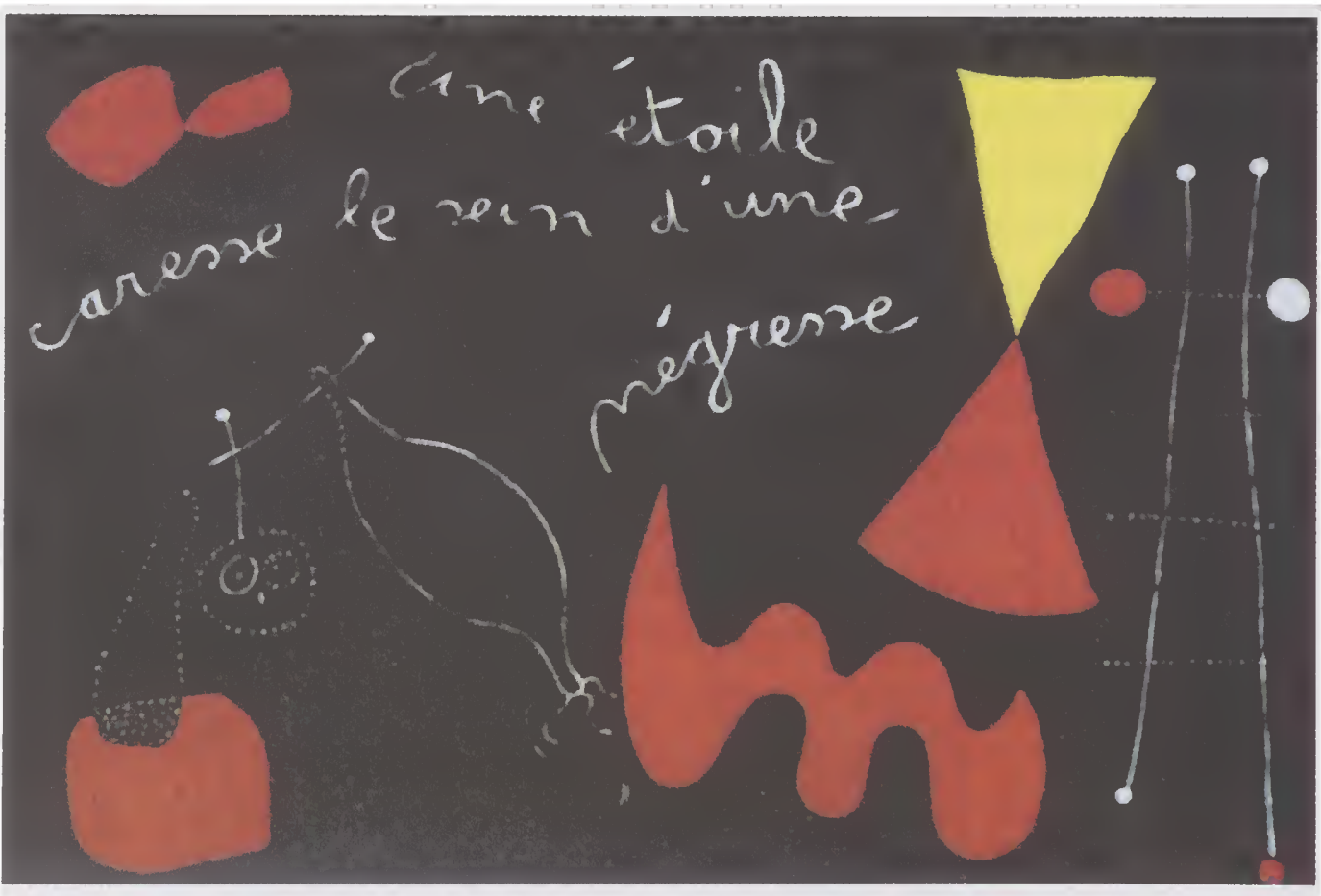

Porque, en el fondo, los componentes semióticos de cuadros como los que acabo de mencionar circulan y esbozan, más allá de lo visible, los rasgos primitivos sobre los cuales reposan y transitan las partículas de lo figural, en la acepción que este término toma cuando 
convenimos con seguidores de la teoría greimasiana en la existencia de unidades del contenido menores que los semas. Ese dinamismo sobrepasa la relatividad de las formas semánticas que se engendran a partir de los componentes sémicos y, por tanto, siempre será posible escuchar el ritmo de lo figural si aproximamos el oído al trasfondo de los sememas o, dicho de otra manera, se conseguimos acercarnos a los valores incógnitos de los fenómenos sensibles de la denotación primigenia que todo sistema connotado esconde. Tal vez la intuición de ese susurro de trasfondo que se adhiere a la denotación primigenia haya sido el estopín del alfabeto inventado por Miró para expresar sus constelaciones ${ }^{14} \mathrm{o}$ de la invención de recursos efectuada por Marey - y seguida de cerca por Duchamp en Le Nu descendant une escalier - para figurar fotográficamente el movimiento de un ser humano. Y creo que Greimas vislumbra la importancia de esa denotación primigenia cuando, después de habernos dicho que Tournier presenta el acontecimiento estético bajo la económica forma de algunas indicaciones somáticas, confiesa, comentando un fragmento del relato del novelista, que

establecida, en el cuadro actancial, entre un sujeto y un objeto de valor. En cuanto a la relación, ella no es "natural"; su condición primera es el detenimiento marcado la propia vivencia es concebida como una relación particular figurativamente por el silencio que bruscamente sucede al tiempo cotidiano, representado como un ruido ritmado. A este silencio corresponde un detenimiento súbito de todo movimiento en el espacio, una inmovilización del objeto-mundo [...] (1999, p. 31)

Las configuraciones propiamente jeroglíficas expresan una modalidad de escritura que se distingue de la puesta en práctica por Magritte y Miró. En ellas, los elementos pictóricos, en cuanto posibles

14. Dicen que un niño le preguntó al pintor lo que significaban sus azules y que el artista le contestó que no se pregunta a los pájaros por el significado de sus cantos, pero que nos gusta escuchar su música. Acerca del alfabeto recomiendo el libro Entendre Miró, de Doménech Corbella. 
unidades sígnicas, no se articulan de manera tan relajada, ya que las imágenes o pictogramas ponen de manifiesto, mediante recursos previamente codificados, formas sonoras del habla con las cuales se puede llegar al nombre de una persona o a construir una frase entera. Así, en la trascripción del Papiro de Ani, Wallis Budge (1960) reproduce el antiguo texto egipcio y en muchos de sus pasajes podremos encontrar una configuración en que la figura estilizada de una especie de pilastra es colocada al lado del dibujo del ojo izquierdo de un ser humano para designar al dios Osiris. La sonoridad de tal combinación de imágenes surge en el instante que sabemos que a la pilastra, símbolo del altar, corresponde el sonido "os" y a la figura del ojo el de "iris" El rebus, considerando ese procedimiento, es, pues, un juego de ingenio y, precisamente por eso, no debe resultar extraño el hecho de que esa modalidad de escritura haya sido usada y se use todavía en los contextos más diversificados. Por su carácter enigmático, aparece como entretenimiento en los periódicos y revistas de gran circulación. Pero han sido los artistas quienes le han sacado más jugo. Es bastante conocido el poema de Palatino, obra en que se congregan dibujos, notaciones musicales y letras y, por subsiguiente, se ofrece al lector como un texto en el que la imagen y la sonoridad se relacionan directamente. También conquistó mundo la broma que Duchamp le gasta al cuadro Mona Lisa al darle un nuevo título utilizando para ello un rebus bastante enigmático. Pero pocos son los espectadores, para citar tan sólo otro ejemplo, que notan la presencia de esa forma jeroglífica en la película Passion, de Godard. El film comienza con una panorámica del cielo que precede a una secuencia de obreros trabajando en una fábrica. La combinación de esos dos fragmentos instaura, sin duda, un proceso complejo de relaciones entre signos de sistemas diferentes, mas, desde la perspectiva jeroglífica, la panorámica puede ser leída como trascripción de la palabra inglesa "god" y la secuencia como una designación "art" $\mathrm{O}$ sea: "god" + "art" = Godard 15

15. En verdad, esta lectura no es mía. Está en estudio acerca del papel de los créditos en en textos fílmicos escritor por un autor(a) francés cuyo nombre, infelizmente, no recuerdo. 
De todos modos los procesos de escritura sobredeterminados por títulos verbales y configuraciones plásticas repercuten - y no podría ser diferente - en los fenómenos semánticos de la intertextualidad y, a medida que de ellos emana una cierta tensión, renuevan constantemente las valencias de signos verbales y no verbales. Hay que reconocer, por consiguiente, que, si admitimos el concepto de valencia definido por Fontanille/Zilberberg (1998, pp. 5-15), lo dialógico de que nos habla Bajtín puede ser captado a partir de las intensidades de la "voz", ya que para el pensador ruso las relaciones dialógicas

son posibles no sólo entre enunciados relativamente) completos, sino también con respecto a cualquier parte significante del enunciado, incluso con respecto a una palabra aislada, si ésta no se percibe como palabra impersonal de una lengua, sino como signo de una posición, ajena de sentido completo, como representante de un enunciado ajeno, es decir, si percibimos en ella una voz extraña. Por eso las relaciones dialógicas pueden penetrar en el interior de los enunciados. Incluso dentro de una palabra aislada si en ella se topan dialógicamente dos voces [...] (1993, p. 257)

Para Steiner (1985, p. 60), la intertextualidad hace que una obra de arte se escuche en otra. Pero las tensiones de tal espejismo irrumpen en los procesos dialógicos cuando los actos de escucha intertextuales, pienso yo, se presentan como un juego de posiciones y distancias a través de las cuales el espacio y el tiempo marcan, de algún modo, su presencia. Y, claro, ese juego actualiza las particularidades de un tempo sobredeterminado por las correlaciones entre valencias perceptivas constituyentes de las bases del dialologismo intertextual que se manifiesta en las configuraciones de la escritura jeroglífica.

Sí uno se fija en este rebus-collage ${ }^{16}$ (figura a seguir), podremos constatar que la urdimbre de la escritura jeroglífica tiene

16. Este es el tercero de los cuatro rebus-collage de Simone Benmoussa publicados en Cahiers Renaud Barrault, $n^{\circ}$ 99. Paris: Gallimard, 1979. 
muchos matrices. Tomando como referencia el orden de las letras y la discontinuidad de los lexemas verbales, los componentes del texto jeroglífico se combinan asumiendo posiciones que tienen, en primera instancia, la función de fornecer pistas de lectura.

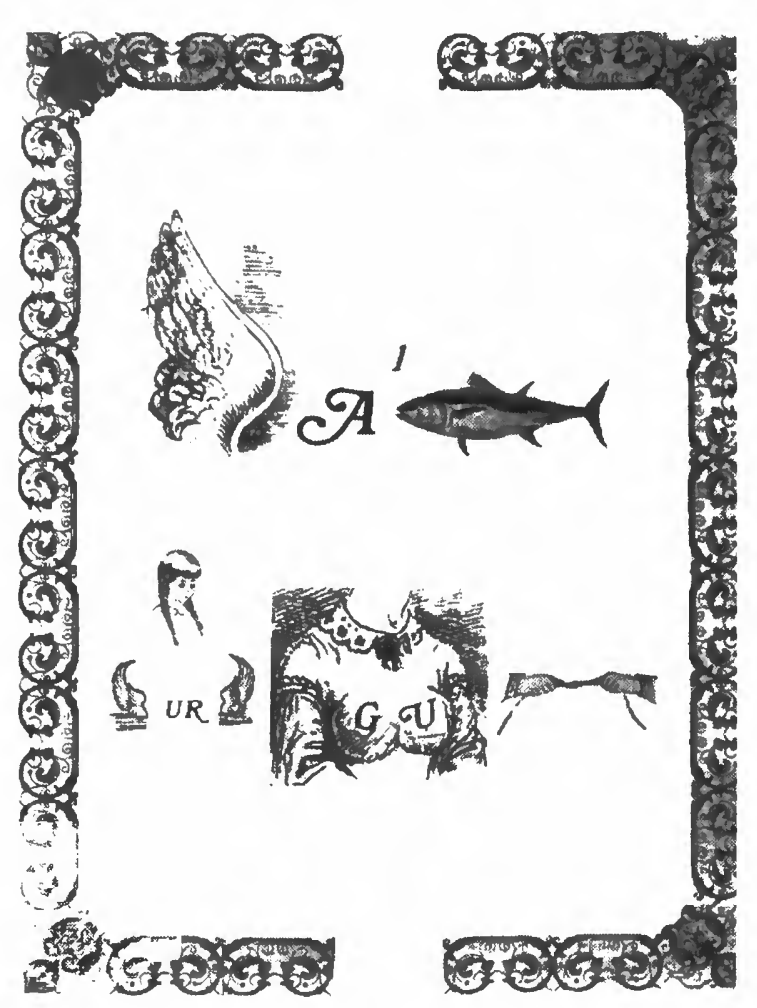

Basándose en ellas y considerando que la codificación previa del rebus es determinada por sonidos de la lengua francesa, la frase que se escucha en esta composición es la siguiente: "Elle a un ton naturel et singulier."' "Ella tiene un aire natural y singular"] Eso porque el primer dibujo evoca el sonido/ elle/ (aille[ala]); la letra A el sonido /a/; el número 1 el sonido /un/; el dibujo del pez/thon/ ["atún"]; el dibujo de las trenzas de la niña remite a /natte/; la sílaba $U R$ entre dos alas a /ur ailé/; los pechos de la mujer sobre los cuales se colocan las letras $G$ y $U$ a /seingu/; y, finalmente, el dibujo de las manos que anudan la cuerda a /lier/. Sin embargo, una vez que se ha descifrado el mensaje que se ocultaba tras las imágenes, pasamos a tener conciencia de que en el enunciado a que llegamos no tienen lugar otros elementos provenientes de las evocaciones sonoras o de las sensaciones que la composición jeroglífica posibilita. Por ejemplo, no caben en ese enunciado formas del contenido sobredeterminadas por las relaciones y correlaciones de rasgos clasemáticos y tímicos adheridos a las formas que representan los senos de la representación de una mujer adulta o de la cabeza de una niña con trenzas. Se ha privilegiado, por consiguiente, una "variación de tonicidad" (Fontanille/Zilbergerg, 1998) y sobre ella se ha fundamentado la interpretación o lectura propuesta, sin que eso signifique, evidentemente, que otros matices de tonicidad no puedan ser explorados y que, por tanto, en los diferentes tipos de escritura pueda ocurrir que esos matices se topen dialógicamente. 


\section{Lectura de un autorretrato de Frida Kahlo}

No es mi propósito construir un modelo aplicable a la lectura de una imagen. Sería pretencioso, porque, sobre eso ya se ha escrito mucho y ya existe un ramo de la semiótica visual que, en estos últimos años, ha hecho progresos encomiables ${ }^{17} \mathrm{Mi}$ intención no va más allá de una tentativa de abordar una variación de tonicidad en un texto pictórico. Para eso, parto del presupuesto de que ciertos conceptos de la semiótica greimasiana o de inspiración greimasiana y el dialogismo bajtiniano pueden aliarse para organizar prácticas interpretativas que aún no fueron, a lo que me es dado saber, realizadas. Aunque sé que no me dejaré guiar por el rigor que tal propuesta requiere, mi deseo básico es contar algo del relato que, en cuanto observador de un cuadro de Frida Kahlo, se engendra en ese instante en que, al olvidar mi condición de destinatario y trasformarme en sujeto, podré encarnar el papel de quien pretende conseguir un contacto más íntimo y, por eso mismo, más afectivo, con un determinado objeto de valor. Sin abdicar de mi vocación apícola, seguiré, en mi tarea de acercarme con cautela al cuadro, un modesto esbozo de lectura ensamblado con algunas células de esa colmena epistemológica en que ciertas ideas de teorías distintas conviven harmónicamente. Me atraen, sin duda, los presupuestos híbridos y, al leer el hermoso libro de Juan Antonio Ramírez titulado La Metáfora de la Colmena (1998), se afianzó mi confianza en la creencia de que así como los fundadores de La Ruche, a comienzos del siglo XX, se entregaron a la aventura de hacer realidad la identificación de los artistas con los insectos melíferos, esto es, de los artistas que liban en diferentes flores para fabricar productos que siempre tienen algo en común, muchos de los que en la actualidad nos dedicamos al estudio de la semiótica podemos, también, libar en teorías diferentes sin que eso

17. Véanse,para citar tan sólo algunos ejemplos, obras como Identités Visuelles, de Jean-Marie Floch (1995), Sémiotique du visible, de Jacques Fontanille (1995) Semiotica dell invisibile, de Lucia Corrain (1995), Figurativização e Metamorfose, de Ignácio Assis Silva (1995), Précis de sémiotique générale, de JeanMarie Klinkerberg (1996), La mirada cercana, de Santos Zunzunegui (1996), y Os Significados Urbanos, de Lucrécia D’Alessio Ferrara (2000). 
represente ningún tipo de aberración y, sobre todo, sin que eso signifique enredarse en los entrecejos de los acérrimos defensores del mito de que existen sistemas inconciliables. Libar, en fin, en un enunciado modal que se manifiesta en el cuadro y del cual derivan sugestivas irradiaciones de sentido.

Con respecto a ese principio es ejemplar la obra Ensayos de Semiótica Tensiva, de Claude Zilberberg (2000). En ella se reúnen, por primera vez, un conjunto de trabajos publicados anteriormente en diferentes revistas. Mas son precisamente los dos últimos capítulos, constituidos por estudios inéditos, los que formulan una síntesis perfecta de lo que entiendo por vocación apícola, ya que en ellos se entretejen, con refinada maestría, ideas de autores como Greimas, Br?ndal, Cassirer, Lévi-Strauss, Aristóteles, Wölfflin y Freud ${ }^{18} \mathrm{O}$ sea, partiendo del presupuesto de que la semiótica constituye, en el fundo, una sólida medotología de las ciencias humanas, Zilberberg construye esquemas en que se juntan categorías semánticas, antropológicas, psicoanalíticas, filosóficas y poéticas, pues, para él, existen cuatro teorías fundamentales del discurso: la de Freud, la de Br?ndal, la de Greimas y la de Lévi-Strauss. Admite, sin embargo, que, en el estado actual de los conocimientos, es necesario agregar a las grandes categorías semióticas las nociones de tempo, figura, esquematización y estilo, reconociendo que este último "llega a ser una manera de sentir y una manera de hacer." (2000, p. 237). A todo eso hay que añadir, por un lado, que Bajtín, aunque se haya dedicado con exclusividad al estudio de textos literarios, admitía que las relaciones dialógicas son posibles también entre otros fenómenos interpretables, si estos fenómenos se expresan mediante alguna clase de material sígnico, por ejemplo, entre imágenes de ostras artes. (1993, p. 258) y que, por otro, como afirma Janice Helland, el reduccionismo psicológico que pone en

ecuación las imágenes sangrientas y brutales de la obra de Kahlo con su deseo de "tapar con pintura" su

18. Claro que los esfuerzos de integración realizados por Zilberberg no se restringen a la esquematización de ideas de estos autores: existen ideas de otros pensadores

Significação $20 \bullet 50$ 
accidente, su sufrimiento y sus dolores, no hace justicia a su obra. Reduce un grupo importante de pinturas realizadas por una artista hondamente intelectual y comprometida socialmente a un mero grito visual de angustia personal. Pero ésta no era la intención de Kahlo. Puesto que se hizo adulta tras la revolución mexicana y alcanzó la madurez cuando el indigenismo y la mexicanidad eran fuerzas poderosas de su país, debemos esperar hallar referencias al nacionalismo romántico. Y puesto que se trataba de una persona política, debemos esperar ver reflejada su política en su arte. (1997, p. 14)

Más que el nacionalismo romántico me interesa el indigenismo y, de manera especial, la iconografía a través de la cual se manifiestan

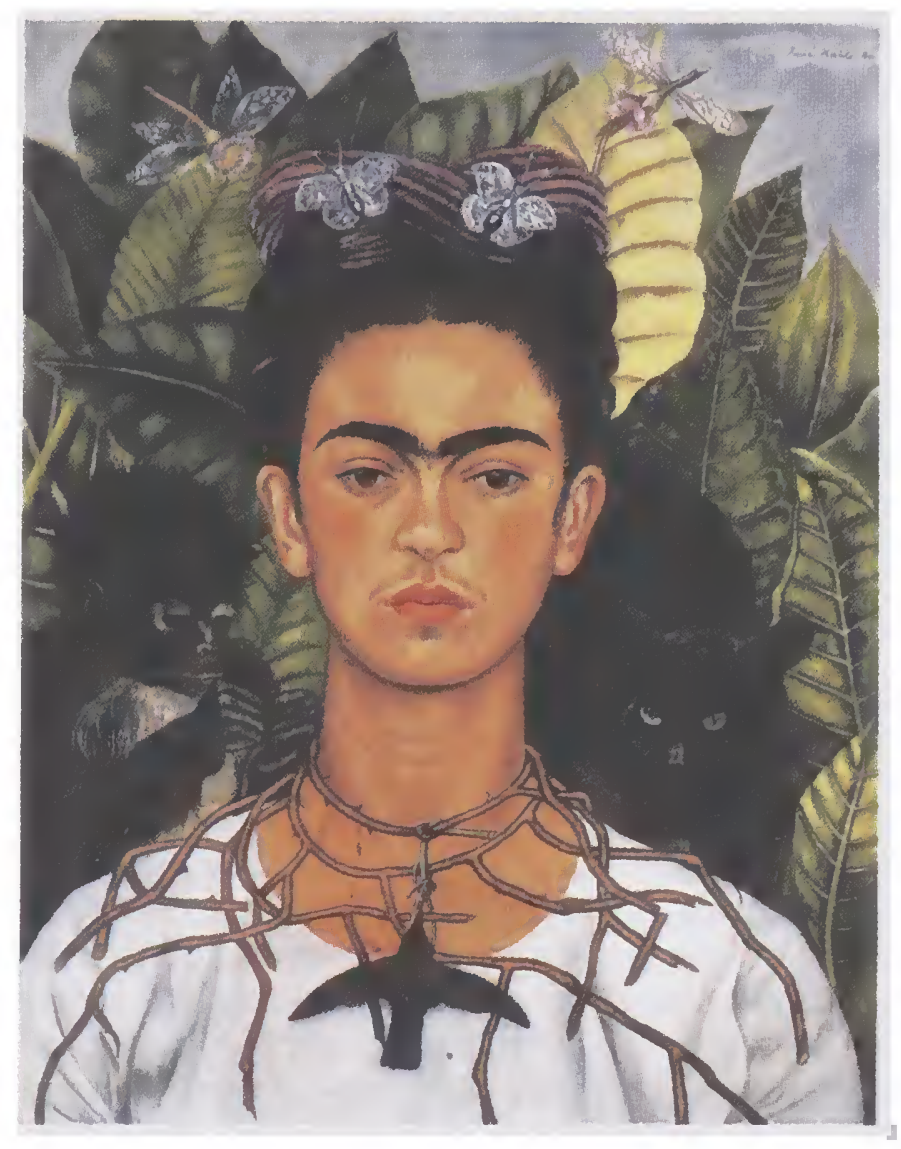
aspectos que valoran una visión amerindia en que la escritura jeroglífica - y en su ámbito, el rebus desempeña papel bastante significativo. En realidad, mi objetivo se resume en una tentativa de interpretar una configuración metafórica que se manifiesta en Autorretrato con collar de espinas y colibrí ${ }^{19}$. Deseo tan sólo explorar una variación de tonicidad en un texto pictórico y,

- la referencia bibliográfica fornece un cuadro amplio - que complementan los varios esquemas montados por el investigador.

19. La reproducción de los dos autorretratos de Frida Kahlo que aquí se transcribe fue realizada a partir de tarjetas postales. 
dentro de los límites de este trabajo, rozar el dialogismo que tal proceso insinúa cada vez que uno se adentra en la obra de Frida Kahlo con la intención de sentir algo del tempo y del ritmo de los lenguajes que ahí se entrelazan para colocar ante la mirada de su espectador un chispazo tónico, un destello poético. Dar, por consiguiente, un paso hacia ese trozo de vida que, en tanto recorrido del sujeto, se preserva a través de una configuración jeroglífica.

Puesto eso, me parece conveniente advertir que en mi esbozo de interpretación no hay lugar para ese tipo de comentarios forjados, con diferentes tenores de apasionamiento, por casi todas las biógrafas que, entre otras cosas, se dedicaron a la tarea de buscar en los autorretratos de la pintora mexicana trazos que servirían para explicar tramos de la sufrida existencia de la artista. Sería incoherente abandonar mi propósito de dejarme encandilar por ese fulgor de acontecimiento que surca la variación de tonicidad del rebus metafórico de la tela, para entregarme, sin más ni menos, a ese ilusorio canto de sirenas que orquestan las feministas con la denotación sonora de la idea de que Frida Kahlo nunca cesó de pintar autorretratos porque "estaba muy sola" (Zamora, 1992, p. 102). Casi todas ellas revolotean, sin que eso signifique disminuir el mérito de sus trabajos, en torno a lo genérico o a ciertas particularidades de la personalidad y los avatares de la pintora que, según ellas ${ }^{20}$ se reflejan en buena parte de los autorretratos que nos dejó la compañera de Diego Rivera.

20. Paradigmas de este tipo de lectura pueden ser encontrados en las interpretaciones que Hayden Herrera hace de algunos de los autorretratos. Así, por ejemplo, sus comentarios a Autorretrato con mono (1996, p. 366) no sobrepasan esa esfera de conceptos centrados en los atributos físicos y sentimentales, tomados en la tradición occidental del autorretrato como una síntesis de rasgos de identidad. Se sabe - y Hélène Samson (2001, pp. 33-40) lo resume bien - que el retrato siempre mantuvo relaciones dialécticas de semejanza y de idealización con el modelo. Cuando mucho, se detiene en aspectos que asumen un carácter meramente amplificante. $Y$ es precisamente ese carácter amplificante que resurge en buena parte de los pasajes de la ficción biográfica montada por Bárbara Mujica en su libro Mi Hermana Frida (2001) o por Meaghan Delahunt en La casa azul de Coyoacán (2002). Las consideraciones que Nancy Frazier (1992, pp. 53-59) hace acerca de Autorretrato con monos no son muy diferentes. Puede decirse que, en la década de los noventa, varias autoras - Malka Drucker (1995), Jane Anderson Jones (1993), etc. -, inspiradas en aspectos más evi- 
Vista en su conjunto, la obra de la elogiada pintora mexicana, presenta, en la esfera iconográfica de la pintura occidental, una característica que me gustaría destacar. Me refiero a la particularidad de que los cuadros fraguados por esta mujer nos llevan a un espacio plástico en que muchas de sus imágenes surgen con la finalidad de suplir iconografías ${ }^{21} \mathrm{o}$, por lo menos, de componer figuras jeroglíficas que difícilmente aparecen en la pintura occidental. Moisés, pintado en 1945, es un derroche iconográfico en que el tema de la fertilidad tiene, según Hayden Herrera (1994, p. 89), un enfoque épico. No cabe duda de que la tela, por la proliferación de acontecimientos e ideas a que los retratos de varios personajes históricos y míticos remiten, posee esa característica. Mas creo que la extensividad que presupone el género épico pierde fuerza cuando constatamos que, mediante una acentuada aglutinación de símbolos, iconos, emblemas y rebus, la composición deja en el espectador una sensación de ritmo determinada por la insinuación de un movimiento que tiene inicio en la dispersión para finalizar en la concentración. En Sin esperanza, también de 1945, también se observa ese movimiento, ese contenido que adquiere su forma sólo cuando lo extraño se hace familiar, fenómeno que ya aparece en Hospital Henry Ford, elaborado en 1932, donde se congregan, en torno a la representación del cuerpo desnudo, un insólito conjunto de configuraciones iconográficas. Podría citar muchos más cuadros, mas creo que los ya citados son suficientes para dar una idea de la particularidad a que me refiero. Una particularidad que, como mostraré más adelante, tiene su origen, creo,

dentes del movimiento feminista, abordan la pintura de Frida Kahlo desde puntos de vista que resaltan la feminidad y el sufrimiento, tópicos sobre los que ya en la década anterior discurrieron pormenorizadamente Raquel Tibol (1983) y Rauda Jamis (1985).

21. Utilizo, por analogía, el siguiente pensamiento de Fontanier: "Mais les Tropes ont lieu, ou par necessité et par extension, pour suppléer aux mots qui manquent à la langue pour certaines idées, ou par choix et par figure, pour représenter les idées sous des images plus vives et plus frappantes que leurs signes propres." ["Mas los Tropos ocurren o por necesidad o por extensión y tienen la finalidad de suplir las palabras que le faltan a la lengua para expresar ciertas ideas o la de representar, a través de opciones y figuras, las ideas con imágenes más vivas y sorprendentes que las de los signos propios." ] (1977, p. 57). No sería correcto de mi parte dejar de citar que también Zilberberg se sirve de esas ideas para introducirnos en sus conceptos de retórica (2000, p. 215). 
en el hecho de que la escritura de Frida Kahlo, al cultivar el recurso de aproximar las cosas que pinta, ostenta su tonicidad a través de configuraciones plásticas comprometidas, de algún modo, con la estructura de las formas jeroglíficas.

Claro que los signos visuales no tienen, como las palabras, diccionarios en que se registren sus respectivos significados y, por esa razón, siempre será imposible saber algo preciso acerca de las iconografías que le faltan a la pintura y, consecuentemente, identificar lo novedoso de una imagen y su grado de originalidad nunca dejará de ser un dilema. Habría que añadir a esos problemas el dato de que aún conocemos muy poco los antecedentes o las etimologías de buena parte de las imágenes constituyentes de nuestro entorno, de nuestras circunstancias cotidianas o estéticas y, al ser la imagen una representación en que se integran elementos de sistemas muy diversos, las propias imágenes nos convidan a que las leamos usando la imaginación, pues, vía de regla, no podemos acercarnos a ellas como quien, prevenido ya de informaciones convencionales, se acerca a una ilustración alegórica semejante a las que, por ejemplo, presenta Cesare Ripa en su Iconología. A pesar de tal dificultad pienso que, en el caso de la pintura de Frida Kahlo, uno puede aproximarse a capas más profundas de significado recurriendo a algunas provisiones iconográficas almacenadas por la cultura amerindia, ámbito en el que la pintora siempre buscó dispositivos sígnicos para la cimentación de sus metáforas más originales.

El collar de espinas del cuadro de Frida Kahlo puede hacernos divagar, tomar los rumbos del devaneo con la misma soltura que revolotean las mariposas representadas en la parte superior de la tela. Asociar, por ejemplo, la configuración a la idea de que ella sería un símbolo de la "mala vida que le daba Diego Rivera" ya que el cuadro fue pintado durante el período de separación entre los dos matrimonios con el famoso muralista. Pero el colibrí aporta otros indicios, principalmente cuando se constata que este pajarillo hace parte de la estructura iconográfica montada para representar a Huitzilopochtli, deidad de la guerra cuyo nombre, traducido al castellano, significa "colibrí a la izquierda" o sea, "colibrí al sur" En general, la imagen de este dios era hecha de madera, detalle 
que parece no habérsele escapado a la pintora y que, de ser así, constituye un indicio bastante sutil de la iconografía en que esa parte del cuadro se inspira. De cualquier modo, Huitzilopochtli, tal cual aparece en los códices, debe ser leído a partir de una transcripción fonético-metafórica de la lengua, pues el colibrí se presenta bajo la condición de una metáfora conceptual para designar el astro solar. Al ser una metáfora que se sirve de determinados componentes de la iconografía original, el sentido que ella adquiere en el contexto semántico del cuadro arraiga en un proceso de desplazamiento: los semas que organizan la forma del contenido de la metáfora originaria se disponen de otra manera en la metáfora creada por Frida Kahlo, motivo que posibilita al sujeto de la lectura lidiar con un semema nuevo, una combinación de partículas de sentido que necesitan también de una iconografía nueva para manifestarse, para, en otras palabras, referirse a posiciones indispensables a la creación de una situación dialógica.

Por otro lado, es posible que esa "lucha" iconográfica, mítica en su esencia, establezca, como una de sus consecuencias, una correlación convergente entre las valencias del símbolo que aludiría a "la mala vida que le daba Diego Rivera" y a los conflictos belicosos adheridos a los significados del dios de la guerra. Mas la hipótesis contraria no debe ser descartada, pues en el enunciado pictórico se aglomeran contenidos que dan margen a que la lectura siga un rumbo diverso y, en el juego de las posiciones dialógicas, las valencias se comprometan con una correlación inversa, esto es, que el sujeto causador de la guerra no sea precisamente el actor Diego Rivera sino la actitud de sujeto encarnado en un mito asumida metafóricamente por Frida Kahlo. De acuerdo con Zilberberg (2000, p. 267), son muchos los mitos que se esfuerzan por establecer y por motivar correspondencias entre tres colecciones: el cuerpo, el mundo animal y el mundo natural. No cabe duda de que, en el cuadro, elementos de esas tres colecciones están representados y, aunque, como ya se ha dicho, partículas de sentido de una configuración iconográfica originaria hayan sido desplazadas, lo que equivale a levantar la hipótesis de que otras hayan sido desalojadas, fuerza será reconocer que, para que exista una auténtica circulación, 
conviene cuidar la posibilidad de un retorno, tratándose de una magnitud caduca del campo discursivo: si la intencionalidad del sujeto es recuperar ( por analogía con el fort-da de Freud en el juego de un niño con un carrete que lanza para luego darse el gusto de traerlo a sí) la magnitud potencializada o virtualizada, lo veremos luego, en continuidad con el esquema narrativo greimasiano, se trataría de actualización. (2000, p. 267)

Son varios los autorretratos que Frida Kahlo pintó en 1940. Pero, para mi propósito, me conviene detenerme en el que le dedicó a su médico (Fig.15). En él, aparentemente, el significado es más directo. Quitando esa mano cortada que funciona como pendiente ${ }^{22}$, las cosas aquí representadas parecen más claras y las metáforas más evidentes mantienen una relación directa con metáforas ya lexicalizadas de la cultura occidental (las gotas de sangre pintadas como perlas).

Sin embargo, como ya nos enseñó la estilística, hay que sospechar de los motivos que se repiten, pues ellos siempre instan, aunque lo hagan de manera velada, a que el observador tope con contenidos cuya índole ominosa conduce, de manera más o menos tortuosa, a sentimientos determinantes de la relación íntima del sujeto con un objeto de valor probablemente sublimado. Las flores son constantes en la

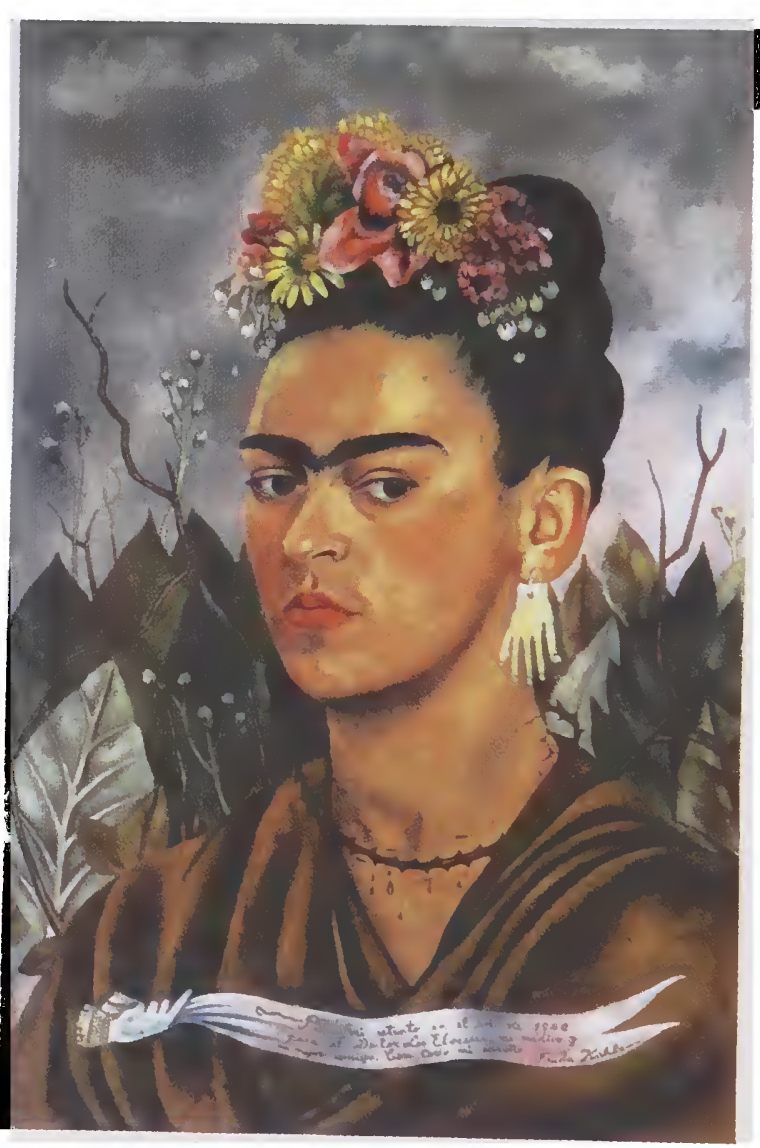

22. Según Herrera (1994, p. 144), los aretes en forma de manos fueron un regalo que "Picasso le diera cuando estuvo en París..."

$\overline{\text { Significação } 20 \bullet 56}$ 
vida y en la obra de Frida Kahlo. Están presentes en numerosas fotografías, en los adornos y, sobre todo, en cuadros de temáticas muy diferentes. Esa presencia es tan fuerte que en varias de sus telas, la flor, representada a veces arcimbolescamente, se impregna de arrebatos eróticos. Con respecto a eso, Hayden Herrera (1994, p. 89) observa que en obras como

En Xóchlitl, flor de la vida, 1938, en La flor de la vida, 1944 y en El sol y la vida, 1947, Frida proyectó su obsesión por la fertilidad en las flores transformándolas en genitales más obviamente masculinos. Las fuerzas sexuales y cósmicas se unen al generar el sol vida; el esperma brota del falo estambre, los lirios que parecen una vagina se abren $y$ los fetos crecen en matrices de pétalos.

La relación de conjunción con las flores se presenta, pues, de muy diversas maneras en las imágenes pictóricas creadas por la artista mexicana, pero en determinadas ocasiones, esas imágenes exhiben las propiedades de la escritura jeroglífica. Eso es lo que ocurre en los dos autorretratos aquí reproducidos. En el primero, la forma jeroglífica surge cuando percibimos que el brillo del plumaje del colibrí es un sema que funciona como el término intermediario de una metáfora en que el término de llegada es mujer. El brillo, combinado con la suavidad, es algo precioso, algo que ondula como ondula el movimiento suave de un cuerpo de mujer. El colibrí no es sólo una parte de la iconografía destinada por la culta azteca a la representación del dios Huitzilopochtli, sino también una especie de lexema plástico en que la dimensión tímica de la preciosidad se alberga en los recintos más profundos de las formas del contenido que, en el contexto semántico de ese cuadro, el lexema en cuestión conquista. O sea, la preciosidad asume un valor intenso, tan intenso cuanto el cromatismo que la representación del pájaro y su posición en el cuadro abiertamente anuncian. Esa metáfora hace su trampa, pues, como ya se ha dicho, desplaza uno de los componentes semánticos $\mathrm{y}$, mediante ese recurso poético, se prepara el terreno para la actualización, ya que el desplazamiento implanta un tempo 
progresivo que permitirá que el elemento tímico mantenga con la flor una relación de no-disyunción.

En Autorretrato con collar de espinas y colibrí, la metáfora que tiene su punto de intersección en "preciosidad" juguetea con esa "preciosidad" de joya que adquieren las mariposas antes de transformarse en flores o insectos. Ese procedimiento instituye, en este metatexto ${ }^{23}$ que estoy poco a poco construyendo, una correlación conversa que sirve para preparar el viaje de los semas atributivos de pájaro, colibrí en el caso, para otra especie de ave. Tal transporte es retóricamente realizable por el hecho de que la metáfora que vengo comentado es el resultado de la articulación de dos sinécdoques provenientes de una descomposición por suma lógica (Groupe $\mu$, 1970, p. 109). Basándome en las propiedades de esa metáfora, creo que el proceso de desplazamiento se pone de manifiesto al homologar las dos metáforas que participan del juego poético armado por Frida Kahlo. Así, puedo afirmar que "brillo" : "sol" :: "preciosidad" : "flor"

Mas como el término sol ya es el resultado de una sustitución - en la configuración jeroglífica, el sol sería Huitzilopochtli -, "brillo" y "preciosidad" se combinan y solicitan la forma expresiva conveniente para que se establezca la relación de semiosis. De modo que, aun admitiendo que se excluya la figura del dios, ese metasemema se expresa en el cuadro de Frida Kahlo a través de una expresión jeroglífica en la que la representación pictórica de la flor se junta a la imagen del pájaro para dar origen a un rebus en el que se escucha el nombre de Xochiquetzal.

Podría argumentarse que en la iconografía del Códice Borbónico, por ejemplo, la diosa aparece adornada con flores y plumas de quetzal. Creo que ese detalle, en el juego de metáforas que el cuadro desencadena, poco importa, pues "colibrí" y "plumas de quetzal" significan "preciosidad" Lo relevante es observar que ese proceso de identificación se encarna, con emoción honda, en el sujeto

23. El término metatexto tiene, en Sémantique Structurale (1966, p. 99), una acepción operacional, lo que no impide que Greimas diga, en ese momento, que su entendimiento del metatexto entre, según él, en conflicto con las ideas freudianas sobre el plano latente y el manifiesto de un texto. Creo que hoy en día ese conflicto ya está completamente superado, como Zilberberg deja claro en varios de sus ensayos. 
que pinta un cuadro para darle forma plástica a una voz que nos dice: "Yo soy Xochiquetzal." Para instituir, por consiguiente, un enunciado modal en el que se entrecruzan, de manera intensa, dos categorías volitivas responsables por la producción de un grito poético cuyo valor se consagra a través de una tajante afirmación de querer ser, de una contundente identidad con la diosa Xochiquetzal, que, segundo nos legaron mitos primitivos, era la esposa de Tláloc, dios de la lluvia y después fue raptada por Tezcatlipoca, dios-padre y sol nocturno y, finalmente, llegó a ser, a lo que dicen, la esposa de Pilzintecutli, dios divino, dios príncipe, primer hijo o sol en nacimiento, asociado a veces con la figura de Quetzalcóatl. En Autorretrato con collar de espinas y colibrí se condensan, pues, dos dimensiones míticas - la que se produce a partir de la iconografía analógica en que se plasma la identidad física de la pintora y la que resulta del rebus mediante el cual se designa el nombre de la diosa indígena - que articulan un enunciado en el que confluyen voces provenientes de universos culturales y temporalidades muy diferentes, mas, no por eso, exentos de dialogar entre sí. Creo, resumiendo, que ese diálogo no ha sido aún analizado de manera abarcadora ${ }^{24}$, de manera a aislar la intensidad de sus sentidos y, entonces, dejarse envolver con las resonancias que los signos plásticos manipulados por Frida Kahlo añoran.

\section{A modo de conclusión}

Por lo expuesto ${ }^{25}$ no me será difícil formular, aunque de manera muy concisa, una conclusión. Creo, si me apoyo en las informaciones acerca del film de Julie Taymor y de la figura ya casi mítica de Frida Kahlo, que tanto la película como la obra pictórica pasan por encuadres deformadores. Así, tomando en cuenta la distinción establecida por Metz (1977, pp. 7-8) entre hecho fílmico y hecho cinematográfico, la crítica que los soportes mediáticos de

24. Se ha estudiado mucho, es verdad, el mito Frida Kahlo (Conde, 2001), pero la proyección del mito de Xochiquetzal en la obra de la pintora es algo que queda por hacer.

25. La segunda y la tercera parte de este trabajo deben ser publicadas, en función de su unidad, como un artículo separado. 
nuestros días ponen en circulación cae, casi siempre, en el ámbito de lo que el pensador francés denomina hecho cinematográfico o en lo que Roland Barthes (1967), desde otro punto de vista, llamaba mundano. O sea, en el dominio de un conjunto de datos que se refieren a hechos exteriores a la película entendida como un texto: popularidad de los actores, costo de la realización, experiencia de la directora, trámites atinentes a la obtención de recursos, publicidad, mecanismos de promoción, distribución, peripecias ocurridas durante el rodaje, etc.etc.

Me parece que los medios masivos no están interesados en informar, sino en repetir datos que niegan la información o que, por otras vías, crean una atmósfera de divulgación en la que sólo respira el lugar común, a menudo un lugar alejado de lo que se entiendo por significado y, consecuentemente, por significación. En el caso de la película, por ejemplo, lo que atrae es hacer comentarios sobre la fábula, sobre esa historia vivida por Diego Rivera y Frida Kahlo, sin que nada se nos diga de quiénes son Diego Rivera y Frida Kahlo en sus obras y como los lenguajes del cine pueden decirnos algo sobre eso. Se destaca, por ejemplo, que en el estreno de la película había una muchedumbre de residentes mexicanos manifestándose contra el hecho de que actores gringos interpretasen personajes mexicanos. El film, en cuanto texto y, por tanto, en cuanto vehículo de información o expresión de la poesía no importa y, cuando se habla de él, se dice que es la adaptación de una novela ( $i$ ?) escrita por Hayden Herrera y que Chavela Vargas canta muy bien La pelona ( $i ?)$, título inventado para la canción conocida mundialmente como La llorona. Se habla también del hermoso cuerpo de Salma Hayek, actriz que ya trabajó en filmes como Time Code y que ahí besa con descarada convicción sexual a otra mujer, de que Antonio Banderas encarna la figura de Siqueiros y de muchas otras cosas por el estilo. Además, los críticos, si así podemos llamarlos, nos dicen, puestos a hablar del film, que es un drama, manera cómoda de clasificarlo y, para algunos, merecedor de dos estrellitas y, para otros, cinco. También se ocupan de los cuidados tomados con las cejas de la actriz para que se pareciesen, naturalmente, con las cejas en forma de colibrí de Frida Kahlo. En suma, se discuten datos que, seguro, pertenecen exclusivamente al 
hecho cinematográfico, relegándose al plano del olvido los elementos que constituirían el hecho fílmico, esto es, el análisis de un texto de ficción construido con la intención de decir algo por sí mismo y, con ello, sacar al espectador de la posición pasiva a que los medios de información lo someten sin el mínimo escrúpulo.

No es mi propósito asumir una posición apocalíptica, ni mucho menos el de pensar que, sin las ideas aquí fornecidas a partir de una propuesta de lectura de un autorretrato de Frida Kahlo, el espectador no tiene condiciones de ver bien el film. Lo que se ofrece a la vista puede, obviamente, ser observado y apreciado desde ángulos muy diversos y diferentes. Sin querer imponer nada, me he limitado a buscar algún que otro elemento del hecho fílmico y, con más o menos acierto, he intentado señalar algunos procesos de marginalización y de prepotencia, siempre con la mirada puesta en los mecanismos de represión impuestos por los ideologemas del inconsciente político. Un esfuerzo destinado a rescatar lo que la señora costumbre y el señor hábito diariamente nos usurpan, lo que, como ya mije, me molesta. Amarrado a ese propósito, he tenido el atrevimiento de referirme a significaciones y a escrituras que, si el espectador de la película se dispone a utilizar, podrá, cuando menos, dilatar un poco sus pupilas y buscar el otro lado del sentido que la señora costumbre y el señor hábito esconden. ¿Mi pretexto? Un simple rebus y, tal vez, un poquito de audacia, un poquito de respeto por las culturas que venimos asesinando ya hace muchos siglos. He querido, en fin, esbozar un gesto que rime con los textos que se me ofrecen, como de hermosa manera rima en la película de Julie Taymor la composición que nos presenta la figura de Frida Kahlo confundiéndose con el mural que, entre 1922 y 1923, Diego Rivera plasmó sobre una de las paredes de la Escuela Nacional Preparatoria, confundiendo la corporeidad de la representación de un cuerpo presente con la corporeidad de unas iconografías que nos hablan de un pasado mítico, de los hombres que surgen del maíz, de los personajes del Popol Vuh. En suma, me he atrevido a reclamar mi condición de sujeto de la enunciación de un hecho fílmico, del proceso subyacente a través del cual lo expresado Greimas, "es atribuible a un yo que apela a un $t u ̈ "$ (Filinich, 2002, p. 18) y, para entrar en el hueco que entre esos dos sujetos se forma, he 
jugado con los ecos, básicamente con uno de los ecos, que la cultura amerindia hace llegar hasta mí y que yo he querido que lleguen también a la película y al lector que se disponga, sin abdicar de su condición de espectador, a verla de nuevo, a verla, quizás, con otros ojos.

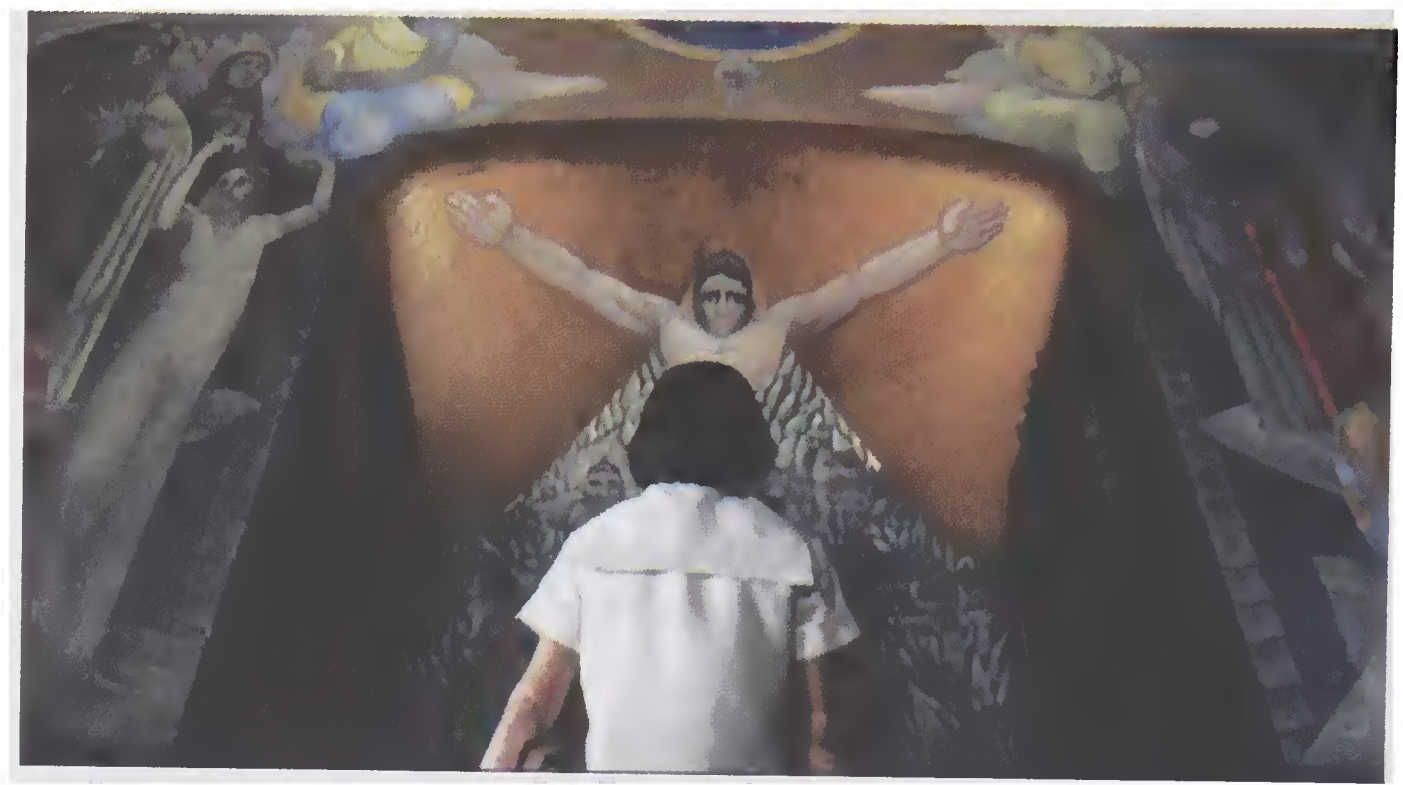

\section{Bibliografia}

AAGE BRANDT, Per .1999. "Magritte: le théâtre de la variation imaginaire", Magritte au risque de la sémiotique de Nicole Everaert-Desmedt (ed.), 71-85. Bruxelles: Publications dês Facultes Universitaires Saint-Louis.

ALCÁNTARA, Isabel; EGNOLFF, Sandra .1999. Frida Kahlo and Diego Rivera. New York: Prestel.

ANDERSON JONES, Jane .1993. Frida Kahlo. New York: Bourke.

ASSIS SILVA, Ignácio .1995. Figurativização e Metamorfose. São Paulo: UNESP.

BAJTÍN, Mijaíl, M. 1993. Problemas de la poética de Dostoievski. México: FCE (Problemy poetiki Dostoievskogo, Mocú: Sovetskaya Rossiya Izdatelsivo, 1978).

CONDE, Teresa del . 2001. Frida Kahlo. La pintora y el mito. México: Plaza Janés. 
La sigilosa sonoridad de un texto plástico: Frida Kahlo...

CORBELLA, Domènec .1993. Entendre Miró. Barcelona: Publicacions Universitat de Barcelona.

CORRAIN, Lucia .1996. Semiotica dell invisibile. Bologna: Ed. Esculapio.

COSTA, Antonio 1995. "Images entre guillemets? La représentation du rêve de Méliés à Fellini", in L'Invention de la Figure Humaine. Paris: Cinémathèque Française.

D'ALESSIO FERRARA, Lucrecia. 2000. Os Significados Urbanos. São Paulo: Edusp/Fapesp.

DELAHUNT, Meaghan. 2002. La casa azul de Coyoacán. Barcelona: Plaza y Janés Editores.

DORRA, Raúl. 1999. "Artes de la mirada", en Fronteras de la Semiótica de Óscar Quezada Macchiavello (ed.), 187-304. Lima: Universidad de Lima: Fondo de Cultura Económica.

FILINICH, María Isabel. 2002. Enunciación. Buenos Aires: Eudeba.

FLOCH, Jean-Marie. 1995. Identités visuelles. Paris: Presses Universitaires de France.

FONTANIER, Pierre. 1977. Les Figures du Discours. Paris: Flammarion.

FONTANILLE, Jacques. 1995. Sémiotique du Visible. Paris: Presses Universitaires de France.

FONTANILLE, Jacques; ZILBERBERG, Claude. 1998. Tension et Signification. Paris: Pierre Mardaga, Éditeur.

FOUCAULT, Michel. 1973. Ceci n'est pas une pipe. Paris: Fata Morgana.

FRAZIER, Nancy. 1992. Frida Kahlo. Mysterious Painter. Woodbridge: Blackbirch Press Book.

GREIMAS, A. J. 1966. Sémantique Structurale. Paris: Larousse.

GREIMAS, A. J. 1990. De la imperfección. Puebla: Universidad Autónoma: Fondo de Cultura Económica - Traducción de Raúl Dorra - (De l'imperfection. Périgueux, Pierre Fanlac Éditeur, 1987).

HELLAND, Jenice. 1997. "Cultura, política e identidaden las pinturas de Frida Kahlo", en Kalías-Revista de Arte, año IX, número 17-18. Valencia: IVAM, pp. 8-14. 
HERRERA, Hayden. 1994. Frida Kahlo. Pinturas. México: Editorial Diana (Frida Kahlo: The Paintings. New York: Harper Collins Publishers, 1991).

HERRERA, Hayden. 1996. Frida. Biographie de Frida Kahlo. Paris: Editions Anne Carrière.

KLINKENBERG, Jean-Marie. 1996. Précis de sémiotique générale. Amsterdan: De Boeck.

MANGUEL,Alberto. 1996. A History of Reading. Toronto: Alfred K. Knopf.

MANOVICH, Lev. 2001. The Language of New Media. Cambridge: MIT.

METZ, Christian. 1977. Langage et Cinéma. Paris: Editions Albatros. MUJICA, Bárbara. 2001. Mi Hermana Frida. Barcelona: Plaza \& Janés Editores, S.A.

PUNYET-MIRÓ, J.; LOVELIER-RAHOLA, G. 1998. Miró, el pintor de las estrellas. Barcelona: Ediciones B.

RAMÍREZ, Juan Antonio. 1998. La metáfora de la colmena. Madrid: Ediciones Siruela.

SALABERT, Pere. 2003. Pintura anémica, cuerpo suculento. Barcelona: Laertes.

SAMSON, Hélène. 2001. "Le portrait et la méditaion de l'identité", Visio 4 (5), 33-40.

SANTOS ZUNZUNEGUI. 1996. La mirada cercana. Barcelona: Paidós.

SILVERMAN, Kaja. 1988. The Acoustic Mirror. Bloomington: Indiana University Press.

STEINER, Wendy. 1985. "Intertextuality in Painting", American Journal of Semiotics, vol.3.n 4 , 57-67.

TIBOL, Raquel. 1983. Frida Kahlo, una vida abierta. México: Biblioteca de las Decisiones.

ZAMORA, Martha. 1992. Frida Kahlo. Paris: Éditions Herscher.

ZILBERBERG, Claude. 2000. Ensayos sobre Semiotica Tensiva. Lima: Universidad de Lima/Fondo de Cultura Económica.

WALLIS BUDGE, E. A.1960. The Book of the Dead. New York: New Hyde Park. 